UNIVERSIDADE DE SÃO PAULO
FACULDADE DE MEDICINA DE RIBEIRÃO PRETO
DEPARTAMENTO DE BIOLOGIA CELULAR,
MOLECULAR E BIAGENTES PATOGENICOS

\title{
Infecções respiratórias por bocavirus humano: aspectos clínicos e moleculares.
}




\author{
UNIVERSIDADE DE SÃO PAULO \\ FACULDADE DE MEDICINA DE RIBEIRÃO PRETO \\ DEPARTAMENTO DE BIOLOGIA CELULAR E MOLECULAR E \\ BIOAGENTES PATOGÊNICOS
}

\title{
Infecções respiratórias por bocavirus humano: aspectos clínicos e moleculares.
}

José Luiz Proença Módena 
JOSÉ LUIZ PROENÇA MÓDENA

\section{Infecções respiratórias por bocavirus humano: aspectos clínicos e moleculares}

Tese apresentada à Faculdade de Medicina de Ribeirão Preto da Universidade de São Paulo para obtenção do título de Doutor em Ciências.

Área de Concentração: Biologia Celular e Molecular e Bioagentes Patogênicos

Orientador: Prof. Dr. Eurico de Arruda Neto

Orgão financiador:

CNPq e FAPESP

RIBEIRÃO PRETO 
Proença-Módena, José Luiz

Infecções respiratórias por bocavirus humano: aspectos clínicos e moleculares

190p.:il.;30cm.

Tese de doutorado, apresentada à Faculdade de Medicina de Ribeirão Preto / USP - Área de concentração: Biologia Celular e Molecular e Bioagentes Patogênicos.

Orientador: Eurico Arruda

1. BOCAVIRUS HUMANO (HBoV)

2. INFECÇÕES DO TRATO RESPIRATÓRIO

3. DIARRÉIA

4. SEQÜENCIAMENTO DE GENOMA COMPLETO

5. CARGA VIRAL (PCR EM TEMPO REAL) 
FOLHA DE APROVAÇÃO

José Luiz Proença Módena

INFECÇÕES RESPIRATÓRIAS POR BOCAVIRUS HUMANO: ASPECTOS CLÍNICOS E MOLECULARES

Tese apresentada à Faculdade de Medicina de Ribeirão Preto da Universidade de São Paulo para obtenção do título de Doutor em Ciências.

Área de Concentração: Biologia Celular e Molecular e Bioagentes Patogênicos

Aprovado em:

Banca Examinadora

Prof. Dr. Eurico de Arruda Neto

Instituição: FMRP-USP

Assinatura:

Profa. Dra. Ângela Kaysel Cruz

Instituição: FMRP-USP

Assinatura:

Prof. Dr. Benedito Antonio Lopes da Fonseca

Instituição: FMRP-USP

Assinatura:

Profa. Dra. Viviane Fongaro Botosso

Instituição: Instituto Butantan

Assinatura:

Profa. Dra. Tiana Kohlsdorf

Instituição: FFCLRP-USP

Assinatura: 
Dedico este trabalko:

À minha noiva e futura esposa Renata Sesti Costa

Pela paciência, dedicação e carinho. En te amo.

Aos mens pais

Por tudo que vocês fizeram por mim. Amo vocês.

À minha irmã

Pelo companheirismo e amizade nesses 29 anos de convivio. Amo você

A todos que diretamente e indiretamente contribuiram neste estudo.

Aos pacientes que participaram deste estudo. 


\section{AGRADECIMENTOS:}

Os meus sinceros agradecimentos:

Ao Prof. Dr. Eurico de Arruda Neto, pela criteriosa orientação, pela amizade e pelo exemplo de paixão à virologia e à ciência.

À Profa. Dra. Tiana Kohlsdorf, pela orientação nas análises filogenéticas e pela oportunidade que me foi concebida de aprender mais sobre evolução e sistemática. Nossas conversas têm sido muito elucidativas.

À Profa. Dra. Ângela Kaysel Cruz, por abrir as portas do seu laboratório e pela simpatia e disposição em sempre ajudar. Os seqüenciamentos realizados nessa tese não teriam acontecido sem isso.

Ao Prof. Dr. Paulo Sérgio Rodrigues Coelho, por abrir as portas de seu laboratório e pela cooperação, conselhos e amizade. Sua ajuda foi essencial para a clonagem e expressão da proteína VP2 desse vírus em leveduras.

Aos Profs. Drs. Luiz Tadeu Moraes Figueiredo, Benedito Antonio Lopes da Fonseca e Vitor Hugo Aquino Quintana, membros do Centro de Pesquisa em Virologia, pelas conversas, conselhos, cooperação e amizade.

Aos Profs. Drs. Otávio Leite Cintra e Ataíde A. Camara, pela colaboração essencial para a obtenção das amostras clínicas.

Ao Prof. Dr. Marcelo Brocchi pela orientação no meu mestrado e pela frutífera parceria. Além de ter sido um grande mestre você tem sido também um grande amigo.

Aos Profs. Drs. Cláudia Maria Leite Maffei e Gutemberg de Melo Rocha pela amizade e pelas inúmeras contribuições.

A todos os membros da banca examinadora pela análise do "boneco" e pelas contribuições que enriqueceram muito esse trabalho.

Aos demais Professores do Departamento de Biologia Celular e Molecular e Bioagentes Patogênicos pelo apoio e pelas disciplinas tão importantes na minha formação.

À Maria Lúcia Silva (Pity), técnica do nosso Laboratório, pela grande ajuda, e pelo imenso carinho.

À Tânia Paula Aquino Defina, técnica do laboratório da Profa. Dra. Ângela Kaysel Cruz, pela paciência, sugestões e indescritível ajuda. Sem você, os seqüenciamentos de genoma completo mostrados nesse estudo não teriam acontecido.

À Soraia, Sueli, “Dona Maria”, Antônia e Eliana, funcionárias do Centro de Pesquisa em Virologia, por tudo que fizeram para que as coisas funcionem no prédio, além da imensa simpatia.

Ao Paulo e Pavaneli, funcionários do Centro de Pesquisa de Virologia, pela ajuda e amizade.

À Marly de Castro por todos os ensinamentos sobre técnicas básicas em microbiologia e pelo carinho.

À Rosangela e Ana, secretárias do departamento, pela grande ajuda e pela prontidão em ajudar, além dos deliciosos momentos de descontração.

À “Dona Inês” e “Dona Lúcia”, funcionárias do Departamento, pela grande ajuda e pelo carinho.

Aos demais funcionários do Departamento de Biologia Celular e Molecular e Bioagentes Patogênicos pela prestimosa cooperação.

Aos meus grandes amigos e companheiros de laboratório, Gustavo, Flávia, Miriã, Humberto, Talita, Rodrigo (Doidinho), Rogério (Carioca), Marcus, André, Reginaldo, Izolete, Andrei, Marisa, Luana, Ariane, Alcir, Alberto e Ana Elise pela grande ajuda e amizade. Apesar de todas as dificuldades, o prazer de conviver com vocês fez desse período um dos mais especiais da minha vida. 
À Thaila Fernanda dos Reis, aluna de doutorado do laboratório do Prof. Dr. Paulo Sérgio Rodrigues Coelho, pela amizade e pela ajuda essencial nas clonagens e expressões realizadas nesse estudo. Aprendi muito com você.

Ao Alberto Anastacio Amarilla Ortiz pela ajuda com alguns dos softwares de bio-informática, incluindo o PAUP e o MEGA.

Aos meus amigos do Centro de Pesquisa em Virologia, por todas as ajudas e pelas conversas na copinha. Todos vocês tem um lugar especial em meu coração.

A todos os amigos e estudantes do Departamento de Biologia Celular, Molecular e Bioagentes Patogênicos.

A todos os amigos da Imunologia e Bioquímica da FMRP-USP.

Aos amigos e amigas, tais como Gabriel (Caprem), Olavo, Leandrinho, Adilson, Jonathas, Patrícia, Fabiana, Juliana, entre outros pela ajuda, amizade e noites de companheirismo.

À minha noiva Renata, pela ajuda no desenvolvimento deste estudo e pelos maravilhosos beijinhos nas horas em que tudo parecia dar errado. Você é especial e me faz muito feliz.

Aos meus sogros, Reinaldo e Ilda, pelo grande apoio e pelo enorme carinho.

Aos familiares da minha noiva, pelos grandes momentos.

À minha irmã, Diana, pelo amor e por todo o carinho.

À minha mãe, Lúcia Maria Proença, pela maravilhosa criação e amor, sem os quais eu nunca estaria onde estou. Acima de tudo mãe, você é um exemplo de bondade.

Ao meu pai, José Luiz Pimenta Módena, pelo exemplo de caráter e por tudo que tem feito por mim. Sem seu incentivo eu não seria um cientista.

À minha família maravilhosa, incluindo avôs, avós, tias, tios, primos e primas.

Aos pacientes, fundamentais para realização deste estudo.

Ao CNPq e à FAPESP pelo financiamento. 
"O única lugar ande a sucessa vem antes do trabalha é na dicionária".

"A mente que se abre a una noua idéia jamais voltará ao seu tamanho original".

Albert Einstein

"Pensar e ser sãa uma e a mesma coisa".

Parmênides 


\section{RESUMO}

Proença-Módena, JL. Infecções respiratórias por bocavirus humano: aspectos clínicos e moleculares. 2009. 118f. Tese a ser defendida na Faculdade de Medicina de Ribeirão Preto Universidade de São Paulo.

O bocavirus humano (HBoV) é um parvovirus recentemente identificado em associação com a presença de sintomas de infecção do trato respiratório. Esse vírus possui um genoma de aproximadamente 5217 nucleotídeos que contém 3 “open reading frames” que codificam 4 proteínas (NS1, NP-1, VP-1 e VP-2). HBoV tem sido detectado em amostras respiratórias de diversas partes do mundo, incluindo Austrália, América do Norte, Europa, Ásia e África, o que sugere uma distribuição global desse vírus. Entretanto, nenhum estudo longitudinal de $\mathrm{HBoV}$ em amostras respiratórias foi realizado na América Latina. Dessa forma, nós realizamos um estudo prospectivo de $\mathrm{HBoV}$ em lavados nasofaríngeos (LFNs) coletados de pacientes com sintomas de infecção do trato respiratório (IRA) atendidos em um hospital universitário de Ribeirão Preto, SP e em um hospital universitário de Salvador, BA no período entre 2005 a 2007. 1288 LFNs de 1217 pacientes foram encaminhados ao laboratório de virologia e foram testados por PCR para HBoV. Desses pacientes, 962 eram menores de 5 anos e 177 eram maiores de 5 anos. Além disso, também foram analisados 50 LFNs de crianças menores de 5 anos que não tinham sintomas respiratórios. Todas as amostras positivas para $\mathrm{HBoV}$ foram testadas para todos os outros vírus respiratórios, incluindo o vírus sincicial respiratório (HRSV), rinovirus humano (HRV), influenza humano (HFLU), metapneumovirus humano (HMPV), parainfluenza humano (HPIV), coronavirus humano (HCoV) e adenovirus humano (HAdV). A carga viral de $\mathrm{HBoV}$ foi determinada por PCR em tempo real em todas as amostras positivas e o genoma completo de 19 amostras de HBoV foi seqüenciado. Com intuito, de fazer um levantamento sorológico e determinar sítios replicativos de $\mathrm{HBoV}$, nós ainda clonamos e expressamos em S. cerevisae (Y258) o gene de VP2, que codifica uma das proteínas do capsídeo viral.

A prevalência desse vírus foi de 4,8\% em crianças menores de cinco anos e de 1\% em pacientes maiores de cinco anos. HBoV não foi detectado em crianças sem sintomas. Dos 259 pacientes analisados em 2005, 25 (10\%) foram positivos para HBoV. Esse vírus circulou mais frequentemente em abril, mês de maior incidência do HRSV. Em 2006, HBoV foi detectado em apenas 10 LFNs de 334 (3\%) amostras testadas, sem qualquer pico de freqüência. Em 2007 HBoV foi detectado em 13 de 552 (2\%) amostras, com uma freqüência de detecção um 
pouco maior em junho e julho. Os sintomas mais comumente observados foram rinorréia, tosse, febre e chiado, que foram observados geralmente em mais de $50 \%$ dos casos positivos para $\mathrm{HBoV}$. Não houve uma diferença significativa na prevalência desses sintomas entre as crianças positivas e negativas para $\mathrm{HBoV}$. Entretanto, foi observada uma maior freqüência de diarréia entre as crianças com esse vírus. Nesse estudo também foi documentado uma alta freqüência de co-infecções virais entre os pacientes com $\mathrm{HBoV}$. Os vírus mais frequentemente associados com o bocavirus humano foram: HRSV, HRV e HAdV. Além disso, foi detectado uma maior carga viral media e uma maior freqüência de diarréia nos 15 pacientes com infecção exclusiva por $\mathrm{HBoV}$ do que nos pacientes com co-infecção. Esses resultados mostraram que $\mathrm{HBoV}$ pode alcançar títulos enormes (tão grandes como $10^{14} / \mathrm{mL}$ ) em LFNs de pacientes com sintomas respiratórios e que isso é associado a de diarréia. O seqüenciamento do genoma inteiro de $\mathrm{HBoV}$ realizado nesse estudo indica que a divergência genômica entre as amostras desse vírus é muito pequena. Como conclusão, nós demonstramos que $\mathrm{HBoV}$ circula e é detectado em associação com sintomas de infecção respiratória e diarréia no Brasil. Novos estudos, com um longo acompanhamento em diferentes populações serão necessários para determinar a sazonalidade e o real impacto clínico de HBoV em nosso país. 


\begin{abstract}
Proença-Módena, JL. Respiratory infections by human bocavirus: molecular and clinical features. 2009. 116f. Thesis to be defended. Faculdade de Medicina de Ribeirão Preto Universidade de São Paulo.
\end{abstract}

Human bocavirus (HBoV) is a parvovirus recently identified in association with respiratory tract infections. HBoV 5217 nt genome contains 3 open reading frames encoding four proteins (NS1, NP-1, VP-1 and VP-2). HBoV has been reported in respiratory samples from children in several parts of the world (including Australia, North America, Europe, Asia, and Africa), suggesting that the virus circulates worldwide. However, no longitudinal studies of $\mathrm{HBoV}$ in respiratory samples have been reported in Latin America. We report a prospective study of $\mathrm{HBoV}$ in nasopharyngeal aspirates (NPAs) collected from patients seen for acute respiratory tract infections (ARI) at the University of Sao Paulo Hospital in Ribeirao Preto, southeast Brazil and at the University Hospital in Salvador, Brazil. 1288 NPAs from 1217 patients was submitted to the virology lab for respiratory virus detection from 2005 to 2007 and were screened for $\mathrm{HBoV}$ by polymerase chain reaction (PCR), whom 962 were under 5 years of age and 177 were older than 5 years. In addition, NPAs from 50 children under 12 years without IRA was also tested to $\mathrm{HBoV}$ for PCR. All samples positive of $\mathrm{HBoV}$ was tested for others respiratory virus, including the human respiratory syncitial virus (HRSV), human rhinovirus (HRV), human influenza (HFLU), human metapneumovirus (HMPV), human parainfluenza virus (HPIV), human coronavirus (HCoV) and human adenovirus (HAdV). These samples had their HBoV viral load determined by real time PCR and the viral entire genome of nineteen $\mathrm{HBoV}$ sample was sequenced. We also cloned and expressed in $S$. cerevisae (Y258) the gene of VP2, one protein of viral capside.

The prevalence of this virus was of $4,8 \%$ in children under 5 years and $1 \%$ in adults, both with IRA. HBoV was not found on the patients without symptoms. In 2005, of the 259 patients tested, 25 (10\%) were positive for HBoV. Interestingly, the virus circulated more frequently in April, the month of peak activity of respiratory HRSV. In $2006 \mathrm{HBoV}$ was detected in only 10 NPAs out of 334 samples (3\%) tested, without any notable peak of frequency. In $2007 \mathrm{HBoV}$ was detected in 13 out of 552 (2\%) tested samples with little higher frequency of detection in June an July. Rhinorrhea, cough, and wheezing were observed in more than $50 \%$ of the HBoV-positive children, and no obvious respiratory clinical differences were noted between HBoV-positive and -negative children. However, was noted a higher 
frequency of diarrhea on HBoV-positive patients. In this study was also observed a larger frequency (71\%) of viral coinfections between the $\mathrm{HBoV}$-positive patients. The respiratory viruses more frequently associated with human bocavirus were: HRSV, HRV and HAdV. Interestingly, on the $15 \mathrm{HBoV}$-alone patients was observed a higher viral load and a higher prevalence of diarrhea than $\mathrm{HBoV}$-coinfection patients. These results showed that this virus can reach enormous titles (like $10^{14}$ ) in NPAs from patients with respiratory infection symptoms and this is associated with diahhrea. The entire genome sequencing of $\mathrm{HBoV}$ of our study indicates that the genetic divergence between the $\mathrm{HBoV}$ lineages is small. In conclusion, we demonstrated that $\mathrm{HBoV}$ circulates and is detected in association with respiratory symptoms and diarrhea in Brazil. Long term surveillance will be needed to determine whether or not an $\mathrm{HBoV}$ season occurs and what is the real clinical impact of this virus in our country. 


\section{LISTA DE ILUSTRAÇÕES:}

FIGURA 1 - Microscopia eletrônica de transmissão de partículas virais icosaédricas em LFNs de três pacientes diferentes que possuíam alta carga viral (maior que $10^{8} / \mathrm{mL}$ ) detectável por PCR em tempo real e eram negativas para todos os outros principais vírus respiratórios. Essas imagens foram observadas após uma etapa de clarificação por centrifugação a 5000g por 30 minutos através de um papel filtro dento.22 coloração negativa com acetato de uranila a 4\%. As figuras mostram imagens em um aumento de 60,000 vezes (a e b), 100.000 vezes aumentada (c) e 150.000 vezes (d, e, f). As caixas destacam a parte da figura que é nas micrografias inferiores. Obtido de Brieu et al, 2007 (13). - Página 3.

FIGURA 2 - Esquema mostrando a organização genômica do $\mathrm{HBoV}$, baseado na linhagem NC_007455 depositada no genbank (http://www.ncbi.nlm.nih.gov/sites/ entrez?Db=genome\&Cmd=ShowDetailView\&TermToSearch=18805; data acesso 21.04.2009). O esquema ilustra as regiões codificadoras das quatro proteínas de HBoV: NS1, NP-1, VP1 e VP2, mostrando a localização dessas regiões no genoma em pares de base. - Página 6 .

FIGURA 3 - Esquema ilustrando a estrutura do genoma de três membros diferentes da família Parvoviridae. As setas indicam os promotores e as ORFS dos principais genes, o gene da proteína não estrutural (NS) e a ORF das proteínas do capsídeo (VP). Vale a pena destacar nessa figura as terminações em "hairpins" que são essenciais para a replicação do genoma desse vírus. Nessa figura, essas terminações estão aumentadas em 20 vezes quando comparadas ao resto do genoma. Adaptado de Fields Virology 2008 (11).- Página 7.

FIGURA 4 - Ilustração representando a topologia de superfície de três exemplares da família Parvoviridae calculados a partir da estrutura atômica desses vírus. (A): Um vírus de inseto denominado Galleria mellonella densovirus (GmDNV); (B): Um vírus autônomo de vertebado denominado minute vírus de camundongo (MVM); (C): um dependovirus denominado adeno-associado vírus tipo 2 (AAV-2). Adaptado de Fields Virology 2008 (11). - Página 8.

FIGURA 5 - Esquema geral ilustrando a via de infecção da superfície celular até o núcleo para os parvovirus. A ligação dos diversos parvovirus à superfície da célula pode se dar por meio de diferentes receptores (dependendo do vírus). No esquema acima, foi usado como exemplo o receptor de transferrina (TfR) que é utilizado pelo CPV. Os passos posteriores, que envolvem o endereçamento endossomal, o tráfego dentro da célula e a entrada no núcleo ainda não são completamente entendidos. Adaptado de Fields Virology 2008 (11).- Página 10.

FIGURA 6 - Modelo de replicação do vírus MVM. No núcleo da célula hospedeira a região Aba serve como "primer" para a síntese da fita filha por uma DNA polimerase celular (1). A síntese prossegue até o encontro com a extremidade FGf, quando ocorre a ligação por uma DNA ligase celular (2). Essa região de junção é reconhecida e clivada por uma endonuclease de restrição viral (NS1) (3), fornecendo um novo sítio iniciador para a síntese nucleotídica (4 e 5). Essa síntese leva a re-formação de estruturas em "harpin" nessa extremidade (6) e faz com que a fita filha passe a servir como molde para a síntese de uma fita igual à fita mãe viral (7). Com o avanço da DNA polimerase, a fita mãe original se abre e se estende, servindo novamente como molde para outra fita filha levando a formação de um grande concatâmero (8). Esse concatâmero é então clivado pela endonuclease viral (9) e os produtos podem servir 
como molde para reinício do processo (10 e 11) ou serem encapsidados para a formação de novos vírus (12 e 13) Abreviações: ABa, região palindrômica na extremidade 3' do genoma viral (fita mãe). FGf, região palindrômica na extremidade 5' do genoma viral (fita mãe). T sítio de clivagem por uma endonuclease que é na maioria dos casos de origem viral (NS1). V, é a fita viral de DNA, ou fita mãe ( $\mathrm{V}^{\mathrm{par}}$ fita parental, $\mathrm{V}^{\text {prog }}$ - fita da progênie viral). C, fita complementar e X é um possível sítio de ação de uma topoisomerase. Adaptado de Berns 1990 (12). - Página 14.

FIGURA 7 - Esquema mostrando o transporte nuclear do capsídeo e de suas proteínas durante o ciclo replicativo de um parvovirus. A entrada dos capsídeos virais no núcleo durante o início da infecção (1) e dos capsômeros traduzidos no citoplasma (2) envolve o reconhecimento de sítios de localização nuclear (NLS) presente na região exclusiva de VP1. A saída do núcleo dos "virions" montados (3) envolve o reconhecimento de regiões de exportação nuclear (NES) fosforiladas na porção $\mathrm{N}$ terminal de VP2. Adaptado de Fields Virology (11).- Página 15.

FIGURA 8 - Mapa do vetor pGEM®T-easy (http://www.promega.com/tbs/tm042/ tm042.pdf; data acesso 21.04.09).- Página 34.

FIGURA 9 - Mapa genômico da seqüência de HBoV depositada no GenBank com a denominação de NC 007455, mostrando as regiões de anelamento de todos os "primers" utilizados nesse trabalho. As setas verdes ilustram os "primers" utilizaos para o diagnóstico de $\mathrm{HBoV}$ por PCR convencional. As setas azuis ilustram os "primers" e a sonda utilizados para a quantificação desse vírus por PCR em tempo real. As setas vermelhas e amarelas ilustram os "primers" utilizados para amplificação e sequenciamento de genoma completo de HBoV. - Página 39.

FIGURA 10 - Esquema geral do sistema Gateway (Invitrogen ${ }^{\circledR}$, Carlsbad, CA, USA), conforme manual do fabricante (http://www.invitrogen.com/site/us/en/home/ ProductsandServices/Applications/Cloning/GatewayCloning/GatewayTechnology.htm l; data acesso 21.04.09).- Página 43.

FIGURA 11 - Mapa do vetor pDONR201 (Invitrogen ${ }^{\circledR}, \quad$ Carlsbad, CA, USA) (http://tools.invitrogen.com/ content/sfs/manuals/gateway_pdonr_vectors.pdf; data acesso 21/04/2009).- Página 48.

FIGURA 12 - Mapa do vetor pEGKT de acordo com Mitchell et al., 1993.- Página 49.

FIGURA 13 - Produtos de PCR para detecção de HBoV visualizado em gel de agarose 1,5\% . Em A, temos um gel representativo do ano de 2005, em B de 2007 para amostras de Ribeirão Preto e em C de amostras obtidas de Salvador, BA. Em vermelho estão destacadas as amostras clínicas positivas para esse vírus. O produtos de PCRs tinham o tamanho esperado de 354bp e foram confirmados por sequenciamento. M: Marcador de peso molecular 100bp (Fermentas International Inc, Burlington, CA). As demais colunas dos géis são referentes às amostras clínicas negativas para HBoV.- Página 57.

FIGURA 14 - Frequência de detecção de HBoV nos grupos de pacientes analisados nesse estudo. Página 58.

FIGURA 15 - Representação contínua da distribuição sazonal de HBoV e HRSV em número de amostras positivas durante os anos de 2005, 2006 e 2007 em pacientes com IRA atendidos em Ribeirão Preto.- Página 59. 
FIGURA 16 - Representação contínua da distribuição sazonal de HBoV em proporção de amostras positivas durante os anos de 2004, 2005 e 2006 em pacientes com IRA atendidos em Ribeirão Preto.- Página 60.

FIGURA 17 - Resultado das etapas envolvidas na construção do clone utilizado para a construção da curva padrão de HBoV. (A) produto da PCR com os primers Full4F/Full4R em gel de agarose 0,8\% (M: marcador de peso molecular de 100bp-Fermentas International Inc, Burlington, CA, 1: produto do PCR). (B) produtos da amplificação por PCR com os primers M13F/M13R de clones do produto mostrado em (A) no vetor pGEM ${ }^{\circledR}-\mathrm{T}$ easy (2, 3 e 4). As outras colunas dessa figura mostram o produto do PCR com os primers M13 de reações controle (5e 6). (C) resultado de uma reação de seqüenciamento para o clone 2 do painel B. Em vermelho estão destacadas as regiões de anelamento dos primers para a PCR em tempo real.- Página 67.

FIGURA 18 - (A) curva de amplificação da reação em PCR em tempo real para o vírus HBoV utilizando diluições seriadas decimais do plasmídeo recombinante resultante da clonagem do produto da PCR com os primers Full4F/Full4R no vetor pGEMT® ${ }^{\circledR}$ T easy. (B) curva padrão feita a partir dessas diluições. - Página 68.

FIGURA 19 - A- Curva de amplificação representativa da PCR em tempo real para o vírus HBoV nos pacientes estudados. B- Curva padrão utilizando quatro diluições do plasmídeo pGEM®-T easy + Full4, mostrando que a eficiência da reação permaneceu alta.Página 69.

FIGURA 20 - Gráfico mostrando a quantificação absoluta em cópias/ml de HBoV.- Página 71.

FIGURA 21 - Gráfico mostrando a quantificação relativa à amostra RP071/ de HBoV utilizando a $\beta$ actina como controle endógeno.- Página 72.

FIGURA 22 - Gráfico mostrando a quantificação absoluta em cópias/mL de HBoV normalizada pela $\beta$-actina.- Página 73.

FIGURA 23 - Curva de amplificação (amplification plot) de diversas amostras sabidamente positivas para HBoV obtida por PCR em tempo real após purificação do mRNA total com beads magnéticas ligadas a streptoavidina e retrotranscrição com "primer olido-dT biotinilado". Em (A) é mostrado as curvas de amplificação dß (B) está representado as curvas de amplificação de $\mathrm{HBoV}$ para as mesmas amostras. Vale destacar que todas as amostras positivas para mRNA de $\mathrm{HBoV}$ foram detectadas apenas depois do ciclo 39.- Página 78.

FIGURA 24 - Visualização em gel de agarose 1,5\% dos produtos de PCRs referentes as 20 reações distintas de PCR para amplificar fragmentos gênicos que cubram toda a extensão do genoma de $\mathrm{HBoV}$ (amostra RP254/05). M: marcador de peso molecular 100bp (Fermentas International Inc, Burlington, CA), 1-13: produtos da amplificação com os "primers" desenhados para gerar fragmentos de até 650bp, 14: produtos da amplificação com os "primers" de diagnóstico de HBoV e 15-20: produtos da amplificação com os "primers" desenhados para gerar fragmentos de até 1100bp.Página 79.

FIGURA 25 - Exemplo de alinhamento e montagem de produtos de PCRs subseqüentes utilizados para seqüenciar o genoma completo das amostras de $\mathrm{HBoV}$ analisadas nesse trabalho, utilizando o software Seqman ${ }^{\mathrm{TM}}$ II expert sequence analysis software (DNASTAR 
inc). Nesse exemplo é mostrada a região de intersecção de dois PCRs subseqüentes utilizados para seqüenciar o genoma completo da amostras RP254/05. Várias reações de seqüenciamento foram realizadas para cada produto de PCR.- Página 80.

FIGURA 26 - Cladograma construído com base na seqüência do genoma inteiro de 19 HBoV que circularam em Ribeirão Preto e Salvador e de 52 seqüências depositadas no GenBank. Essa árvore foi gerada por inferência bayesiana, com1500000 gerações, 100 freqüências, 5 corridas e 4 cadeias. O genoma completo de BPV e CnMV foi usado como grupo externo. O modelo de substituição adotado foi o $(G T R+G)$. As freqüências entre os ramos são os valores das probabilidades posteriores. Em verde e amarelo estão destacados os dois clados principais formados nessa análise. Em vermelho estão destacadas as amostras de $\mathrm{HBoV}$ de Salvador e Ribeirão Preto.Página 83.

FIGURA 27 - Cladograma construído com base na seqüência do gene de VP1 de 19 HBoV que circularam em Ribeirão Preto e Salvador e de 52 sequências de VP1 depositadas no GenBank. Essa árvore foi gerada por inferência bayesiana, com1500000 gerações, 100 freqüências, 5 corridas e 4 cadeias. O genoma completo de BPV e CnMV foi usado como grupo externo. O modelo de substituição adotado foi o (GTR+G). As freqüências entre os ramos são os valores das probabilidades posteriores. Em verde, amarelo e azul estão destacados os dois clados principais formados nessa análise. Em vermelho estão destacadas as amostras de $\mathrm{HBoV}$ de Salvador e Ribeirão Preto.Página 84.

FIGURA 28 - Visualização em gel de agarose a 0,8\% dos produtos de PCR referentes a amplificação dos genes VP1 (1) e VP2 (2). A figura A mostra produtos de PCR resultantes da amplificação com "primers" com cauda para recombinação homóloga, enquanto que a figura B mostra produtos dessa mesma amplificação usando "primers” para VP1 e VP2 sem cauda. C(-): controle negativo da reação, M1: marcador de peso molecular $1 \mathrm{~kb}$ (Fermentas International Inc, Burlington, CA), M2: marcador de peso molecular de 100bp (Fermentas International Inc, Burlington, CA).- Página 86.

FIGURA 29 - Esquema ilustrando o resultado da clonagem (A) e das reações de PCR (B) e seqüenciamento (C) para os genes VP1 e VP2 de HBoV. Os produtos observados em B de 1-15 foram obtidos a partir de reações de PCR com os "primers" M13/M13R. Nas colunas 1-5 os PCRs foram feitos a partir de colônias obtidas da clonagem de VP1 com cauda AttB no vetor pGEM-T easy (Promega ${ }^{\circledR}$, Madison, WI, USA). Já as colunas 6-10 e 11-15 ilustram os produtos da clonagem de VP2 com e sem cauda respectivamente. C-: controle negativo, $\mathrm{M}$ : marcador de peso molecular $1 \mathrm{~kb}$ (Fermentas International Inc, Burlington, CA). Em vermelho está destacada as caudas com os sítios de recombinação homóloga.- Página 87.

FIGURA 30 - Visualização em gel de agarose 0,8\% dos produtos de PCRs referentes a amplificação dos genes VP1 (1) e VP2 (2), feitas a partir de um dos clones resultantes da clonagem de VP1 e VP2 no vetor pDONR201. M: marcador de peso molecular 1kb (Fermentas International Inc, Burlington, CA), 1: pENTR-VP1HBoV e 2: pENTR-VP2HBoV.Página 88.

FIGURA 31 - Visualização em gel de agarose 0,8\% dos produtos de PCRs referentes a amplificação do gene VP2 (1, 2 e 3), feitas a partir de alguns dos clones resultantes da clonagem de VP2 no vetor pEGKT. M: marcador de peso molecular $1 \mathrm{~kb}$ (Fermentas International Inc, Burlington, CA), 1, 2,3: pEGKT -VP2HBoV, 4: C-.-- Página 89.

FIGURA 32 - Visualização em gel de poliacrilamida desnaturante (SDS-PAGE 10\%)\% do extrato protéico total de três clones diferentes de leveduras (S. cerevisiae - Y258) expressando 
VP2 de HBoV após transformação com o plasmídeo pEGKT-VP2HBoV. As colunas denominadas de 1 mostram o extrato total das leveduras não induzida enquanto que as colunas 2 e 3 mostram os extratos totais das leveduras que foram induzidas com galactose por 2 horas e overnight, respectivamente. M: marcador GH (Sigma Aldrich ${ }^{\circledR}$, St. Louis, MO, USA). A primeira banda possui 205kDa (Miosina tipo II), a segunda $116 \mathrm{kDa}$ ( $\beta$-galactosidase), a terceira $97,4 \mathrm{kDa}$ (Fosforilase-b), a quarta $66 \mathrm{kDa}$ (soroalbumina bovina) e a quinta de 45kDa (ovoalbumina).- Página 90.

FIGURA 33 - A- Imagem da membrana de nylon corada com Ponceau 0,5\% ilustrando o extrato protéico total de dois clones diferentes de leveduras (S. cerevisiae - Y258) expressando VP2 de HBoV (1, 2 e 3 - um clone e 4,5, 6 outro clone). Os números com linha (1', 2' e etc) mostra os extratos purificados por glutationa-sepharose . 1 e 4: não induzida, 2 e 5 induzidas 2 horas, 3 e 6: induzidas overnight B- Imagem do filme fotográfico após marcação com anticorpo anti-GST. A revelação foi feita por ECL e a exposição foi de 5 minutos. M: marcador GH (Sigma Aldrich ${ }^{\circledR}$, St. Louis, MO, USA). - Página 90. 


\section{LISTA DE TABELAS:}

TABELA 1 - A família Parvoviridae com seus principais representantes.- Página 4.

TABELA 2 - Relação de "primers" utilizados para a detecção por PCR convencional dos oito vírus respiratórios analisados nesse estudo.- Página 29.

TABELA 3 - Relação de “primers" e sondas utilizados para a detecção de HBoV e dф̧ -actina por PCR em tempo real, utilizando o sistema “Taqman” (Applied Biosystems ${ }^{\circledR}$, Foster City, CA).- Página 33.

TABELA 4 - Relação de "primers" usados para o sequenciamento do genoma completo de HBoV. Página 37.

TABELA 5 - Relação de “primers” usados para amplificação de fragmentos grandes do genoma completo de HBoV.- Página 38.

TABELA 6 - Características clínicas e demográficas dos diversos grupos de pacientes.- Página 55.

TABELA 7 - Sintomas, sinais e diagnósticos clínicos dos pacientes com IRA que foram positivos e negativos para HBoV.- Página 62.

TABELA 8 - Sintomas, sinais e diagnósticos clínicos dos pacientes com IRA menores de cinco atendidos em Ribeirão Preto que foram positivos e negativos para HBoV.- Página 63.

TABELA 9 - Frequencia de co-infecção nos pacientes positivos e negativos para HBoV.- Página 64.

TABELA 10 - Vírus respiratórios detectados nas amostras positivas para HBoV.- Página 65.

TABELA 11 - Vírus respiratórios detectados em um subconjunto de 52 pacientes negativos para HBoV. - Página 65.

TABELA 12 - Características cínicas e diagnóstico final dos pacientes com infecção exclusiva por HBoV e dos pacientes infectados com HBoV mais algum outro vírus respiratório. Página 66.

TABELA 13 - Valores da carga viral média de HBoV por PCR em tempo real.- Página 70.

TABELA 14 - aracterísticas cínicas e diagnóstico final dos pacientes com alta e baixa carga viral de HBoV. - Página 76.

TABELA 15 - Padrão de substituição nucleotídica estimada para o genoma completo de HBoV. Página 81. 


\section{LISTA DE ABREVIATURAS E SIGLAS:}

AAV - Adeno-associado vírus

AMDV - "Aleutian mink disease virus"

B19 - Parvovírus B19

BPV - Parvovírus bovino

CDC - "Centers for Disease Control and Prevention"

CnMV - "Canine minute vírus"

CPV - Parvovírus canino

CT - "cycle threshold"

dNTPs - Deoxinucleosídeos trifosfato

DOP - "Degenerate oligonucleotide primed PCR"

FLU - Influenza

FPV - Vírus da panleucopenia felina

GST - Glutationa-S-Transferase

HAdV - Adenovírus

HBoV - Bocavirus humano

HCFMRP-USP - Hospital das Clínicas da Faculdade de Medicina de Ribeirão Preto da Universidade de São Paulo

HCoV - Coronavirus

hLRT - "hierarchical likelihood ratio tests"

HMPV - Metapneumovirus

HPIV - Vírus parainfluenza

HRSV - Vírus sincicial respiratório

HRV - Rinovírus humano

IGC - Índice de gravidade clínica

IRA - Infecção do trato respiratório

IRTA - Infecção do trato respiratório

IVAS - Infecção das vias aéreas superiores

LFN - Lavados nasofaríngeos

MVM - Minute vírus de camundongo

NES - Seqüência de exportação nuclear

NLS - Sítios de endereçamento nuclear

ORFs - "Open reading frames"

PARV - Parvovirus humano

PCR - Reação em cadeia da DNA polimerase

PLA $_{2}$ - Fosfolipase $A_{2}$

RT - Transcrição reversa

TfR - Transferrina

VGDN - "Viral Genetic Diversity Network" 
1. INTRODUÇÃO.

1.1-) Bocavirus humano: Aspectos gerais.

1.2-) Organização genômica, estrutura e diversidade.................................................. 5

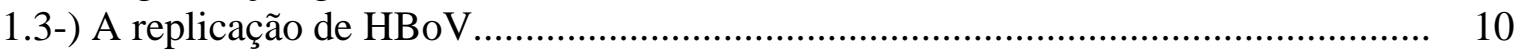

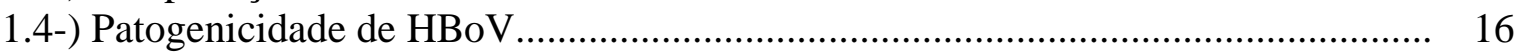

1.4.1-) Bocavirus humano e doenças do trato respiratório....................................... 17

1.4.2-) Bocavirus humano e doenças do trato digestório....................................... 19

1.4.3-) Bocavirus e doença sistêmica, lesões da pele, otite média aguda e

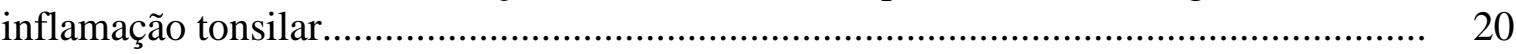

1.5-) Diagnóstico, tratamento e prevenção.................................................................... 21

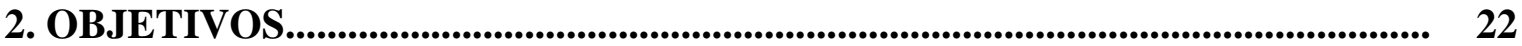

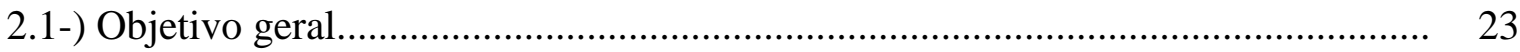

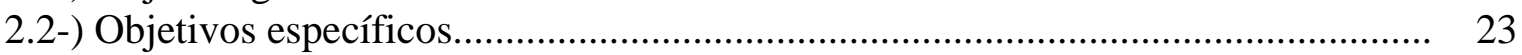

3. PACIENTES E MÉTODOS................................................................................ 24

3.1-) Pacientes e espécimes clínicos................................................................................ 25

3.2-) Extração de DNA e RNA total dos lavados nasofaríngeos.................................. 26

3.3-) Detecção de HBoV por PCR......................................................................... 27

3.4-) Detecção dos demais vírus respiratórios por PCR............................................... 28

3.4.1-) Detecção do vírus sincicial respiratório humano (HRSV) por PCR ......... 30

3.4.2-) Detecção do rinovirus humano (HRV) por PCR...................................... 30

3.4.3-) Detecção do metapneumovírus humano (HMPV) por PCR...................... 31

3.4.4-) Detecção do vírus influenza (FLU A e B) por PCR ................................ 31

3.4.5-) Detecção dos vírus parainfluenza (HPIV) 1, 2 e 3 por PCR...................... 31

3.4.6-) Detecção dos coronavirus humano (HCoV 229E e OC43) por PCR........ 31

3.4.7-) Detecção do Adenovirus Humano (HAdV) por PCR................................ 32

3.5-) Quantificação de HBoV por PCR em tempo real.................................................. 32

3.6-) Detecção de mRNA de HBoV como indício de replicação.................................. 35

3.7-) Amplificação e sequenciamento de todo o genoma de HBoV ............................... 36

3.8-) Edição e alinhamento dos genomas completos................................................... 42

3.9-) Análises Filogenéticas............................................................................. 42

3.10-) Análise dos genomas................................................................................... 42

3.11-) Clonagem e expressão de VP2 de HBoV ........................................................... 43

3.11.1-) Amplificação dos genes VP1 e VP2 de HBoV ....................................... 44

3.11.2-) Ligação ao vetor pGEM®-T Easy (Promega)......................................... 45

3.11.3-) Preparação de E.coli DH10- $\beta$ competentes para eletroporação............... 45

3.11.4-) Eletroporação................................................................................... 46

3.11.5-) Extração Plasmidial, PCR e sequenciamento dos clones

3.11.6-) Clonagem dos genes VP1 e VP2 no vetor de entrada do sistema

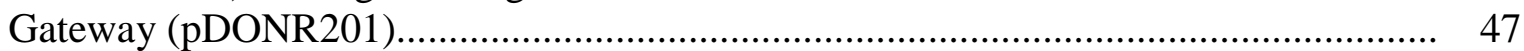

3.11.7-) Subclonagem de VP1 e VP2 no vetor de expressão em leveduras (pEGKT).

3.11.8-) Transformação em S. cerevisiae (Y258)..

3.11.9-) Expressão de VP2 em S. cerevisiae (Y258) e extração das proteínas totais. 


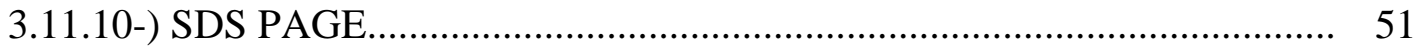

3.11.11-) Purificação de VP2 recombinante...................................................... 51

3.11.12-) "Western blot”........................................................................... 51

3.12-) Gráficos e análises estatísticas....................................................................... 52

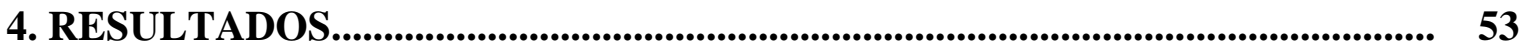

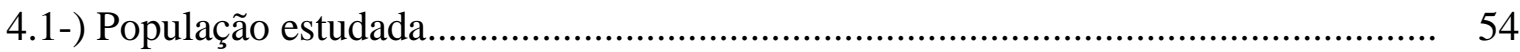

4.2-) Prevalência e Distribuição sazonal de HBoV ....................................................... 56

4.3-) Características clínicas dos pacientes infectados com HBoV ............................... 61

4.4-) Coinfecções entre vírus respiratórios.................................................................... 63

4.5-) Análise quantitativa do DNA de HBoV no aspirado nasofaríngeo......................... 67

4.6-) Detecção de mRNA de HBoV como indício de replicação.................................. 76

4.7-) Sequenciamento do genoma inteiro e análise filogenética das amostras de

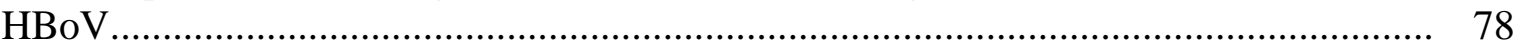

4.7-) Clonagem de expressão de VP2 de HBoV ..................................................... 85

5. DISCUSSÃO

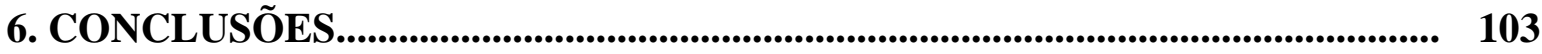

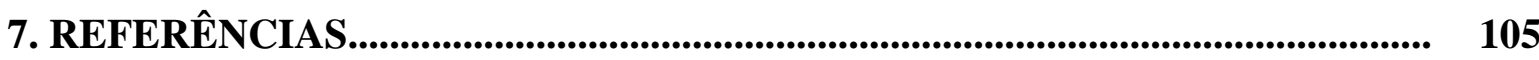

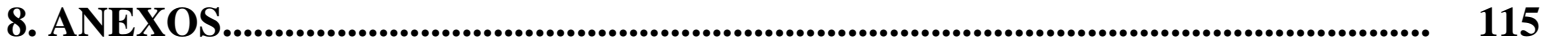




\section{INTRODUÇÃO}

\section{1-) Bocavirus humano: Aspectos gerais.}

O Bocavirus humano (HBoV) é um vírus de DNA de fita simples, não envelopado, icosaédrico (FIGURA 1) que foi primeiramente descrito em lavados nasofaríngeos (LFNs) de crianças suecas que apresentavam sintomas de infecção do trato respiratório (IRTA), mas que não tinham nenhum agente etiológico conhecido detectável (1). A identificação de HBoV foi feita através de um elegante ensaio metagenômico, composto por um passo de purificação viral, seguido por uma amplificação pela reação em cadeia da DNA polimerase (PCR) com "primers" hexaméricos randômicos contendo caudas que funcionaram como alvos de “primers” para outras PCRs, cujos produtos foram clonados e seqüenciados (1). Desde então, $\mathrm{HBoV}$ tem sido detectado por PCR em todo o mundo, principalmente em crianças com sintomas de infecção do trato respiratório ou digestório (2-8).

Esse vírus é pertencente à família Parvoviridae, subfamília Parvovirinae, gênero Bocavirus (9). A família Parvoviridae é composta por duas subfamílias, a subfamília Densovirinae que é composta por vírus que infectam invertebrados e a subfamília Parvoviriane que infecta vertebrados. Esta última é composta por 5 gêneros, denominados Parvovirus, Eritrovirus, Dependovirus, Amdovirus e Bocavirus (TABELA 1) (9, 10).

Os vírus do gênero Parvovirus, cujos representantes mais conhecidos são os vírus da pancoleucopenia felina e o parvovirus canino, são caracterizados por possuírem um genoma de aproximadamente $5 \mathrm{~kb}$ que apresenta apenas duas regiões promotoras e um único sítio de poliadenilação (11). No geral, os membros do gênero Parvovirus são vírus que infectam animais domesticáveis e causam gastroenterites e miocardites graves, com grande importância em saúde veterinária (11). Já o gênero Eritrovirus é composto pelo Parvovírus Humano B19 e outros vírus a ele relacionados. Esse vírus foi o primeiro representante da família Parvoviridae que foi associado a infecções no homem. Esse vírus foi identificado pela primeira vez em 1974 em um "screening" de doadores de sangue e o seu nome foi derivado do código da amostra (11). Esse patógeno é geralmente associado a eritema infeccioso na infância, podendo ocasionar quadros graves, como artropatias agudas, crise aplástica transitória, hidropsia e miocardite. Ele apresenta um forte tropismo pela célula progenitora da linhagem eritróide, portadora do antígeno do grupo sangüíneo P na medula óssea ou no fígado 
fetal (11). Os membros desse gênero são caracterizados por possuírem um genoma com um único sítio promotor e dois sinais de poliadenilação $(11,12)$. O gênero Amdovírus é composto pelo vírus AMDV (“Aleutian mink disease virus”) e outros relacionados a ele. Os vírus desse gênero possuem dois sítios promotores e dois sinais de poliadenilação. Já o gênero Dependovirus é composto por vírus que dependem para a sua replicação da coinfecção em uma mesma célula hospedeira com outro vírus, denominado vírus acessório, que é, na maioria das vezes, um adenovírus ou um herpesvírus (11).

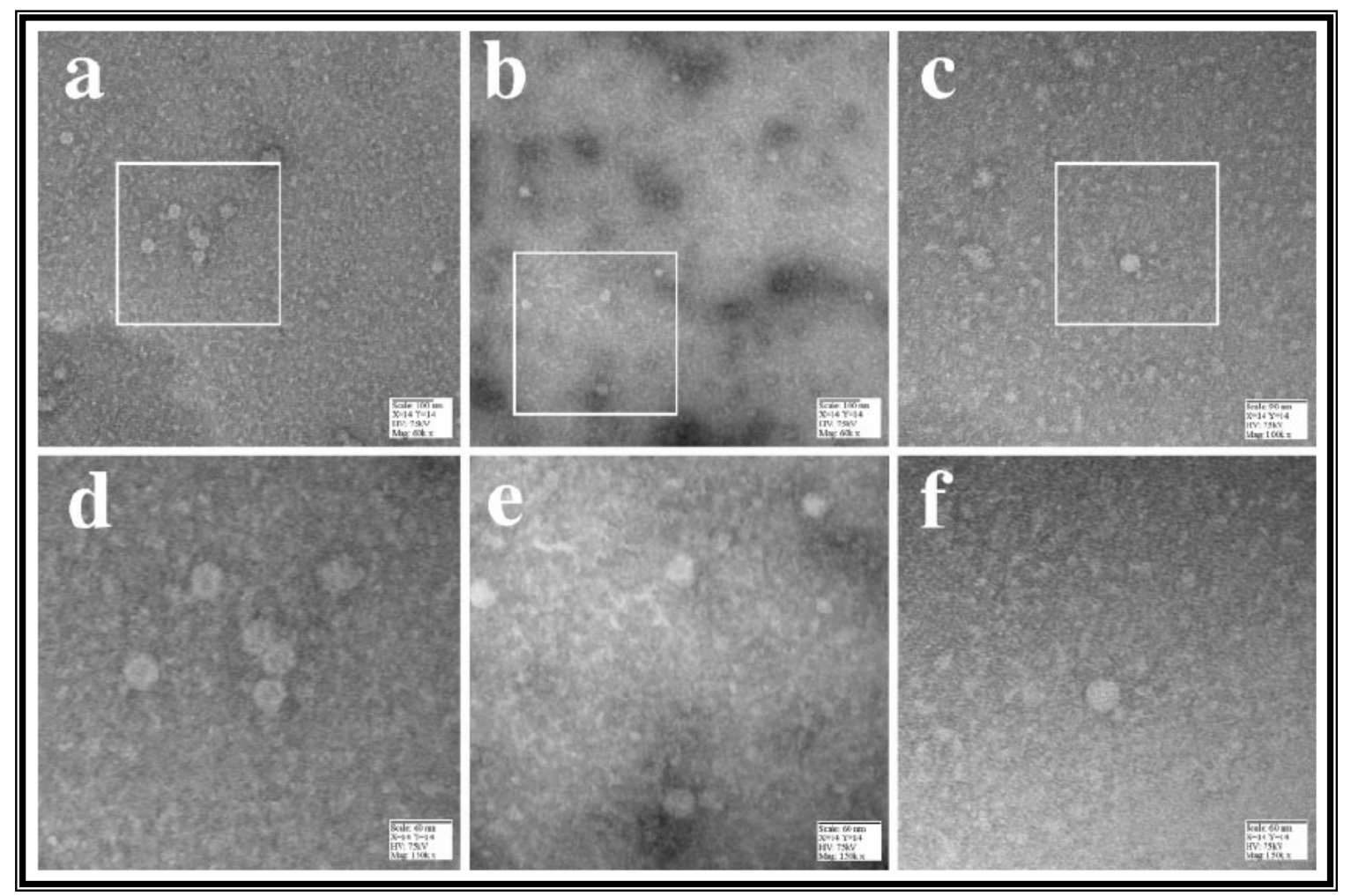

FIGURA 1. Microscopia eletrônica de transmissão de partículas virais icosaédricas em LFNs de três pacientes diferentes que possuíam alta carga viral (maior que $10^{8} / \mathrm{mL}$ ) detectável por PCR em tempo real e eram negativas para todos os outros principais vírus respiratórios. Essas imagens foram observadas após uma etapa de clarificação por centrifugação a 5000 g por 30 minutos através de um papel filtro de $0.22 \mu$ e colora̧ão negativa com acetato de uranila a 4\%. As figuras mostram imagens em um aumento de 60,000 vezes (a e b), 100.000 vezes (c) e 150.000 vezes (d, e, f). As caixas destacam a parte da figura que é aumentada nas micrografias inferiores. Obtido de Brieu et al, 2007 (13).

O gênero Bocavírus é formado por vírus com genomas de aproximadamente 5.4 kb, que possuem uma terceira região promotora em seu genoma. Esse gênero é composto por apenas três espécies, o CnMV (“canine minute vírus”), o BPV (parvovírus bovino) e o $\mathrm{HBoV}$, objeto desse estudo (9). O CnMV é associado a doenças neonatais e desordens de fertilidade em cachorros $(14,15)$. Os sintomas dependem de qual momento da gravidez a infecção ocorreu e variam de reabsorção do feto, aborto, deformidades e menor tamanho dos filhotes (10). Já o BPV causa doenças gastroentestinais e do trato respiratório em bezerros e 
problemas reprodutivos para o rebanho. Os sintomas clínicos variam de diarréia moderada e vômitos a miocardites, abortos, leucopenia e linfopenia (10).

TABELA 1. A família Parvoviridae com seus principais representantes.

\begin{tabular}{|c|c|}
\hline \multicolumn{2}{|c|}{ Família Parvoviridae } \\
\hline Subfamília Parvovirinae & Subfamília Densovirinae \\
\hline 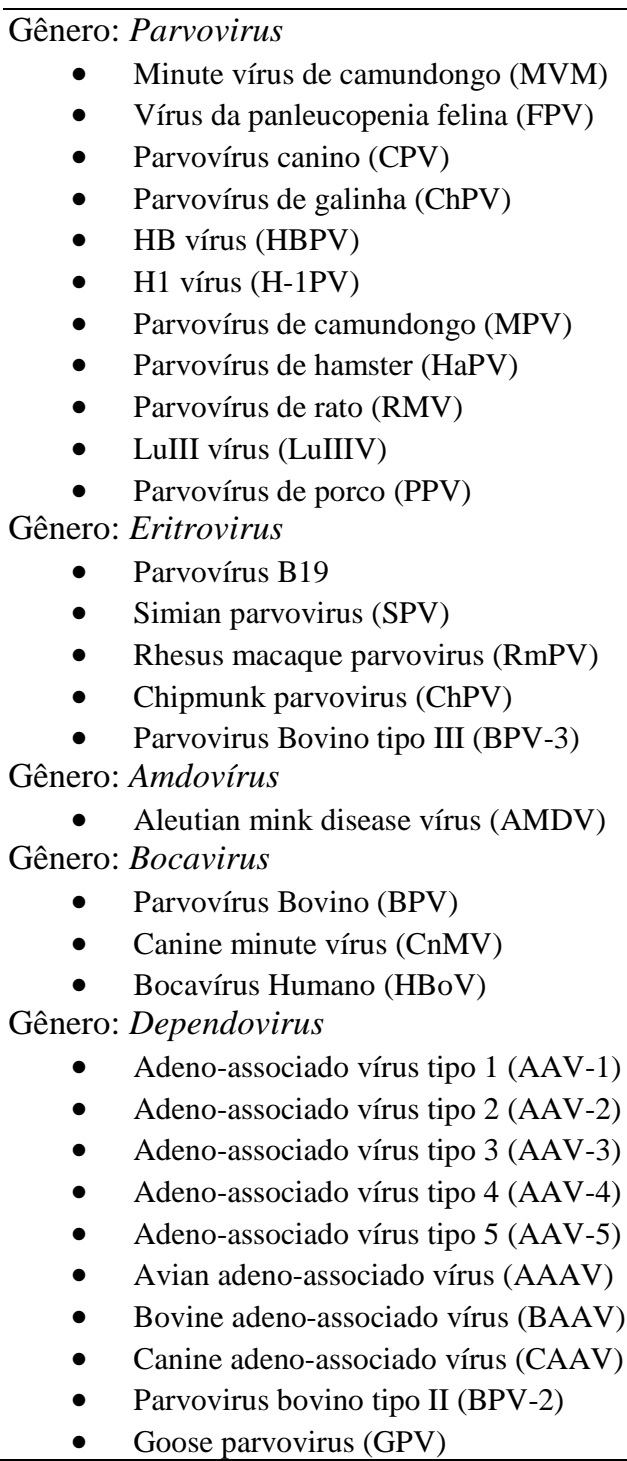 & $\begin{array}{cl}\text { Gênero: } & \text { Densovirus } \\
\text { - } & \text { Junonia coenia densovirus (JcDNV) } \\
\text { - } & \text { Galleria mellonella densovirus (GmDNV) } \\
\text { - } & \text { Diatraea saccharalis densovirus (DsDNV) } \\
\text { - } & \text { Mythimna loreyi densovirus (MIDNV) } \\
\text { Gênero: Iteravirus } \\
\text { - } \quad \text { Bombyx mori densovirus (BmDNV) } \\
\text { - } \quad \text { Casphalia extranea densovirus (CeDNV) } \\
\text { Gênero: Brevidensovirus } \\
\text { - } \quad \text { Aedes aegypti densovirus } \\
\text { - } \quad \text { Aedes albopictus densovirus (AalDNV) } \\
\text { - } \quad \text { Aedes pseudoscutellaris densovirus (ApDNV) } \\
\text { - } \quad \text { Simulium vittatum densovirus (SvDNV) } \\
\text { Gênero: Pefudensovirus } \\
\text { - } \quad \text { Periplaneta fuliginosa densovirus (PfDNV) } \\
\text { - } \quad \text { Acheta domesticus densovirus (AdDNV) } \\
\text { - } \quad \text { Planococcus citri densovirus (PcDNV) }\end{array}$ \\
\hline
\end{tabular}

O Bocavírus humano é detectado em pacientes com sintomas de infecção do trato respiratório em várias regiões do mundo, com freqüência variando de 3,9\% a 24\% para pacientes com sintomas de infecção do trato respiratório superior (16, 17), 11 - 26\% para bronquiolite graves $(2,16,18)$ e 4,9 - 33\% para pacientes com pneumonia $(2,16,17)$. Esse vírus é ainda detectado em 2-25\% de pacientes com gastroenterites (19, 20) e em 32-45\% de pacientes com inflamação das adenóides e tonsilas $(6,21)$. O papel desses vírus no 
desenvolvimento desses sintomas clínicos é ainda controverso e será discutido adiante nesse texto.

Recentemente, um novo vírus da família Parvoviridae, denominado parvovirus humano 4 (PARV4), foi detectado em plasma humano usado na fabricação de produtos medicinais (22). Entretanto, esse vírus ainda não foi classificado (9) e nenhum quadro clínico foi associado a ele (22).

\section{2-) Organização genômica, estrutura e diversidade.}

O bocavirus humano possui um genoma de aproximadamente 5,3 kb, com três “open reading frames” (ORFs). Duas dessas ORFs codificam proteínas não estruturais, denominadas NS1 e NP-1, enquanto que a terceira ORF localizada mais a jusante no genoma codifica as duas proteínas do capsídeo viral, denominadas VP1 e VP2 (1) (FIGURA 2). A seqüência codificadora de VP2 está contida dentro do gene de VP1, no mesmo "frame" de leitura, fazendo com que a seqüência 3'de VP1 seja idêntica a VP2 (1). VP1 é na verdade uma VP2 com 387 nucleotídeos a mais na sua região 5', a região exclusiva dessa proteína (FIGURA 2).

Até o presente momento, mais de 50 genomas completos estão disponíveis no GenBank (http://www.ncbi.nlm.nih.gov/sites/entrez), mas acredita-se que a sua estrutura ainda não foi completamente elucidada (23). Os genomas dos parvovirus possuem em suas duas extremidades estruturas complexas que formam "hairpins" resultantes de várias seqüências palindrômicas presentes nessas regiões do genoma (FIGURA 3). Essas conformações secundárias da fita simples de DNA são essenciais para a replicação do genoma viral dos membros da família Parvoviridae, mas não foram ainda caracterizadas para o $\mathrm{HBoV}$ (23, 24). O ciclo replicativo de HBoV será discutido posteriormente nesse texto. 


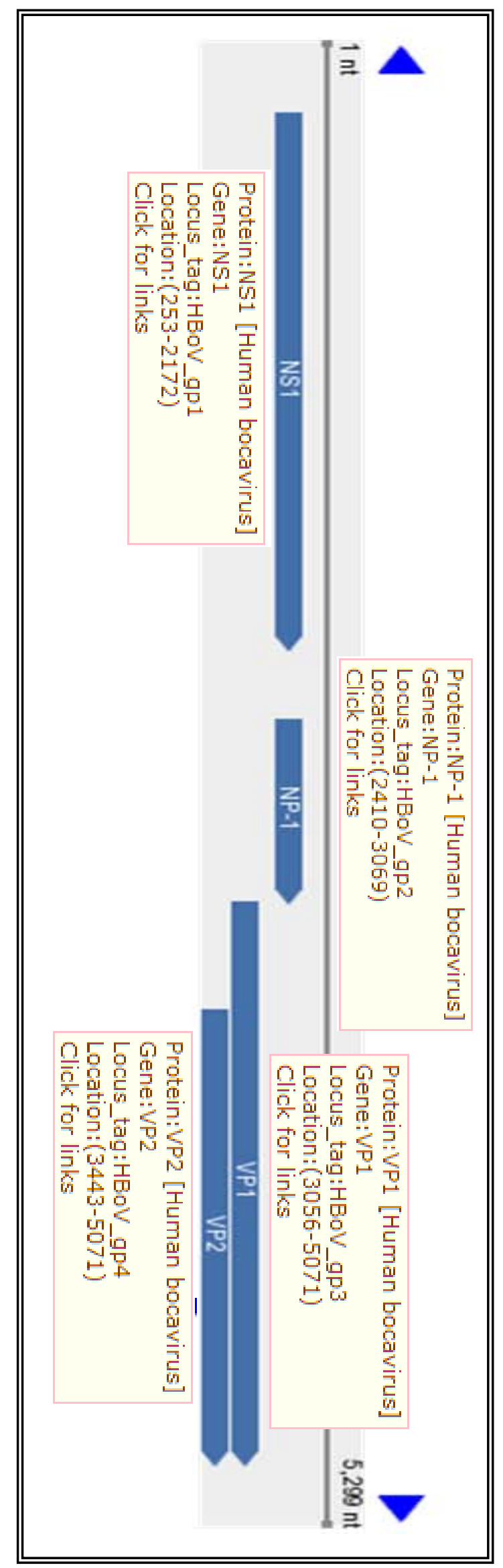

FIGURA 2. Esquema mostrando a organização genômica do HBoV, baseado na linhagem NC_007455 depositada no genbank (http://www.ncbi.nlm.nih.gov/sites/entrez?Db=genome\&Cmd=ShowDetailView\&Term ToSearch=18805; data acesso 21.04.2009). O esquema ilustra as regiões codificadoras das quatro proteínas de HBoV: NS1, NP-1, VP1 e VP2, mostrando a localização dessas regiões no genoma em pares de base. 


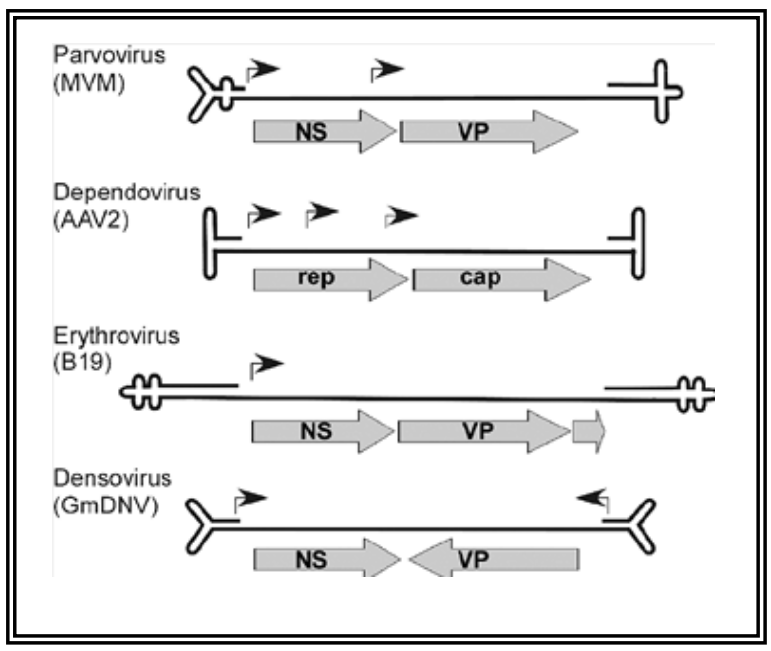

FIGURA 3. Esquema ilustrando a estrutura do genoma de três membros diferentes da família Parvoviridae. As setas indicam os promotores e as ORFS dos principais genes, o gene da proteína não estrutural (NS) e a ORF das proteínas do capsídeo (VP). Vale à pena destacar nessa figura as terminações em "hairpins" que são essenciais para a replicação do genoma desse vírus. Nessa figura, essas terminações estão aumentadas em 20 vezes quando comparadas ao resto do genoma. Adaptado de Fields Virology 2008 (11).

As estrutura atômica e a forma pela qual as proteínas estruturais de $\mathrm{HBoV}$ se unem para formar o capsídeo viral ainda não foram elucidadas. Entretanto, a estrutura atômica de alguns membros dessa família já foi descrita o que possibilitou a construção de modelos que ilustram a topologia de superfície desses vírus (FIGURA 4) (11).

No geral, as proteínas estruturais (que podem ser apenas VP1, ou VP1 + VP2 ou VP1 + VP2 + VP3 dependendo do vírus) se juntam em capsômeros que se agrupam em montantes de 60 e formam um capsídeo icosahédrico com 18 a 26 nm de diâmetro e peso molecular de 5,5 a 6,2Ã (11). Esse capsídeo pode apresentar pequenas protuberâncias e grandes depressões circundando o eixo central, que são essenciais para a biologia do vírus, como determinantes de tropismo no hospedeiro, ligantes de receptores e importantes sítios para a ligação de anticorpos e para o desenvolvimento de inibidores estruturais específicos (11). Essas protuberâncias e depressões são mais nítidas nos vírus que infectam vertebrados do que nos exemplares da subfamília Densovirinae (FIGURA 4). 


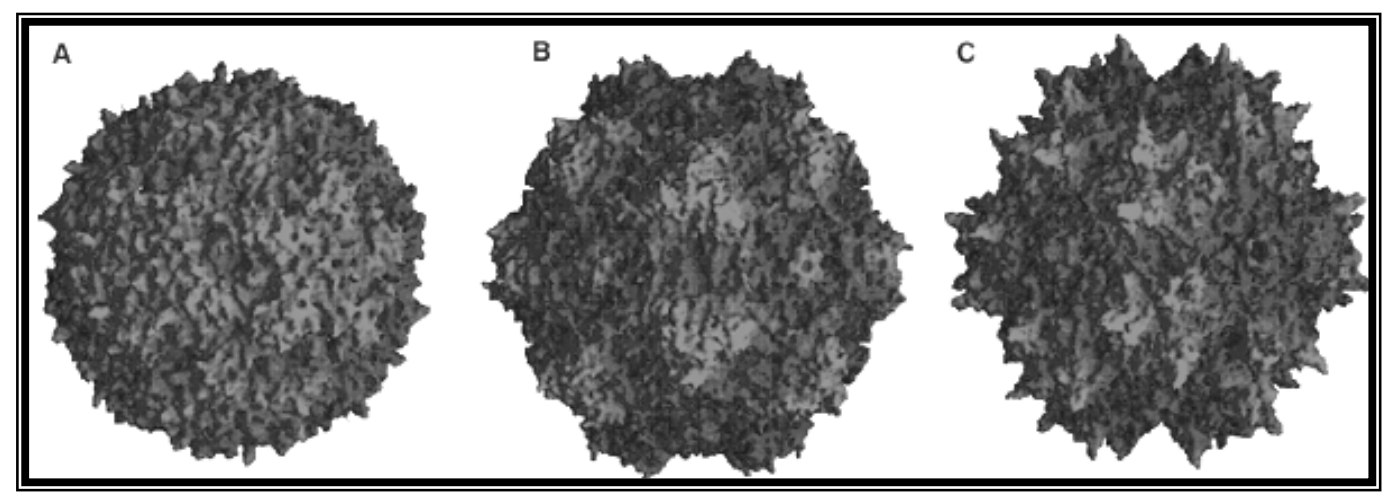

FIGURA 4. Ilustração representando a topologia de superfície de três exemplares da família Parvoviridae calculados a partir da estrutura atômica desses vírus. (A): Um vírus de inseto denominado Galleria mellonella densovirus (GmDNV); (B): Um vírus autônomo de vertebrado denominado minute vírus de camundongo (MVM); (C): um dependovirus denominado adeno-associado vírus tipo 2 (AAV-2). Adaptado de Fields Virology 2008 (11).

A proteína VP1 possui peso molecular de 80.000 a 86.000 Daltons (Da), enquanto que VP2 e VP3 possuem peso molecular de 60.000 a 75.000 Da e 60.000 a 62.000 Da, respectivamente (11). VP3 e é uma proteína presente em CnMV, BPV e outros parvovirus e é o resultado de uma clivagem proteolítica de VP2 (11). Essa proteína ainda não foi descrita em $\mathrm{HBoV}$. A região exclusiva de VP1 possui atividade enzimática de fosfolipase $\mathrm{A}_{2}\left(\mathrm{PLA}_{2}\right)$ dependente de cálcio. Essa atividade de fosfolipase $\mathrm{A}_{2}$ é essencial para a replicação viral de vários parvovirus, incluindo o parvovirus B19, pois ela é de crucial importância para a liberação do vírus do lisossomo depois da entrada na célula (25). Além disso, a região Nterminal de VP1 também contém “motifs” de aminoácidos básicos que funcionam como sinal para a localização nuclear (11). Nenhuma dessas proteínas são glicosiladas, mas elas possuem vários sítios de fosforilação (11).

Além das proteínas do capsídeo, o genoma de $\mathrm{HBoV}$ codifica duas proteínas não estruturais denominadas NS1 e NP1 de 75.000 e 28.000 Da, respectivamente (1). As funções dessas proteínas nesse organismo ainda são desconhecidas, mas elas podem ser especuladas pelo que se sabe dessas proteínas nos outros membros dessa família. A proteína NS1 é essencial para a replicação do DNA em outros parvovirus, uma vez que ela está envolvida com a ligação e hidrólise de nucleotídeos trifosfato e possui atividade de helicase (26). A proteína NP1 não é encontrada nos outros representantes da família Parvoviridae, sendo exclusiva do gênero bocavirus (10). A sua função é desconhecida, mas acredita-se que ela possa estar envolvida na replicação do DNA viral e na montagem dos “virions”, pois um 
estudo com células infectadas com BPV mostra que essa proteína se encontra ancorada à cromatina dentro do núcleo (27).

Análises filogenéticas de HBoV têm mostrado que, no geral, o genoma desse vírus é altamente conservado, com uma identidade de aproximadamente 98\% (23, 28, 29). A maior variação ocorre nas regiões codificadoras de VP1 e VP2, que possuem identidade de 98,7\% e 98,2\% respectivamente. As regiões mais a montante de VP1/VP2, responsável pela transcrição de NS1 e NP1 são mais conservadas, com identidade de 99,4\% e 99,2\% respectivamente $(23,28,29)$.

Em um estudo publicado em 2007, Neske et al. (29) analisaram 968bp do gene VP2 de 69 amostras positivas para $\mathrm{HBoV}$ e observaram que as variações ocorreram em apenas 34 posições (3,5\%) das 968 analisadas. As transições (mutação onde uma purina é substituída por outra purina ou uma pirimidina é substituída por outra piridima) representaram 93\%, enquanto que as transversões (mutação onde uma purina é substituída por uma pirimidina ou vice-versa) representaram $7 \%$ das variações. Nesse estudo, foi mostrado também que a maioria das mutações que ocorreram no gene de VP2 era conservativa. A identidade no nível de aminoácidos foi de 99,7\%.

Embora essa variação pareça extremamente baixa, vale destacar que devido ao pequeno tamanho do genoma dos parvovirus, pequenas alterações podem levar a mudanças drásticas na biologia desses vírus. Por exemplo, alterações de uns poucos aminoácidos na estrutura das proteínas do capsídeo podem levar a um escape do sistema imunológico, mudança de receptor ou mesmo de hospedeiro, como observado para o parvovírus canino (CPV), que aparentemente originou-se de um ancestral comum ao vírus da panleucopenia felina (FPV) no início da década de 70 (11). Além disso, o fato do genoma dos parvovirus ser de DNA de fita simples e sua replicação ser processada por uma DNA polimerase celular (que possuí um sistema de reparo dependente da dupla fita do DNA) torna-os teoricamente mais susceptíveis a modificações em curto períodos de tempo.

Acredita-se até o momento que $\mathrm{HBoV}$ exista no mundo inteiro como uma única linhagem composta de dois genótipos sutilmente diferentes que circulam num mesmo lugar em um mesmo período (23, 28, 29). Nenhum trabalho publicado até agora observou uma associação entre clados filogenéticos e distribuição sazonal ou manifestação clínica (23, 28, 29). 


\section{3-) A replicação de $\mathrm{HBoV}$.}

O ciclo de $\mathrm{HBoV}$ e os mecanismos de replicação do seu genoma ainda não foram descritos. O que se conhece foi descoberto estudando o ciclo replicativo de outros parvovirus. No geral, os parvovirus se ligam a um ou mais receptores presentes na membrana da célula hospedeira e entram por endocitose. A seguir são liberados no citoplasma onde, por um processo dependente do citoesqueleto, eles são transportados para a periferia nuclear, onde se dá a entrada no núcleo por um processo ativo (FIGURA 5). No núcleo, esses vírus são desmontados e ocorre a replicação do DNA viral por uma DNA polimerase celular (11).

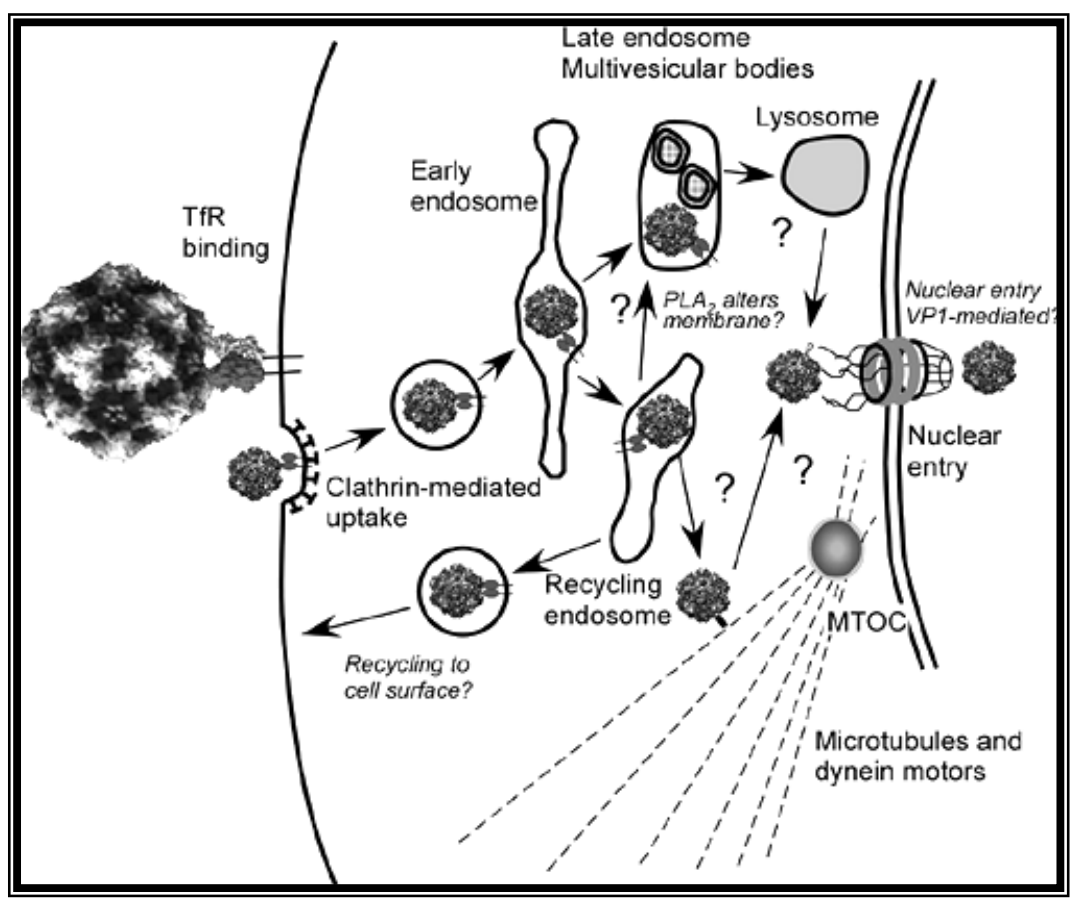

FIGURA 5. Esquema geral ilustrando a via de infecção da superfície celular até o núcleo para os parvovirus. A ligação dos diversos parvovirus à superfície da célula pode se dar por meio de diferentes receptores (dependendo do vírus). No esquema acima, foi usado como exemplo o receptor de transferrina (TfR) que é utilizado pelo CPV. Os passos posteriores, que envolvem o endereçamento endossomal, o tráfego dentro da célula e a entrada no núcleo ainda não são completamente entendidos. Adaptado de Fields Virology 2008 (11).

Diversos receptores já foram descritos para vários membros da família Parvoviridae. Entretanto, nenhum receptor de $\mathrm{HBoV}$, nem seus sítios de replicação no homem foram ainda descritos (23). Um trabalho recente, publicado em chinês, relata indícios de replicação de HBoV em culturas primárias de células epiteliais brônquicas, através da observação de efeito citopático em microscopia óptica após inoculação de espécimes clínicos positivos para esse vírus nessas células (30). 
O parvovirus B19, que também causa infecção no homem, utiliza o antígeno P de eritrócitos ou globosídeo como receptor. Pessoas que não apresentam o fenótipo de expressão desse antígeno são naturalmente resistentes à infecção com parvovirus B19 (31). Os parvovirus CPV, FPV e MVM utilizam glicoproteínas sialiladas como receptor, como, por exemplo, o receptor de transferrina (TfR) $(32,33)$. Já para BPV, um membro do gênero Bocavirus, a ligação do vírus à célula hospedeira é mediada pela glicoforina A, uma glicoproteína que contem ácido N-acetil-neuramínico (34).

Depois da ligação à célula hospedeira, os parvovírus, em geral, entram através de endocitose mediada por clatrina, conforme observado por microscopia eletrônica de transmissão em células infectadas com CPV (35). Uma vez dentro das células, os capsídeos de CPV permanecem dentro dos endossomos por várias horas, até que esses alcancem a região perinuclear (11). Os mecanismos de escape dos parvovirus das vesículas endocíticas ainda não são completamente entendidos, mas sabe-se que eles são dependentes de acidificação endossomal, pois tratamentos com bafilomicina $\mathrm{A}$ 1, cloroquina e $\mathrm{NH}_{4} \mathrm{Cl}$ inibem a replicação viral de $\operatorname{CPV}(35,36)$. Além disso, a atividade $\mathrm{PLA}_{2}$ presente na região exclusiva de VP1 também é essencial para o escape dos endossomos e a conseqüente liberação no citoplasma de CPV e outros parvovirus. Essa atividade de PLA 2 também foi descrita para a região exclusiva de VP1 em HBoV (37). Foi observado que o tratamento com inibidores de $\mathrm{PLA}_{2}$ inibe a proliferação de vários representantes da família Parvoviridae in vitro (38).

Depois de liberados no citoplasma, os capsídeos virais são transportados ativamente até a membrana nuclear. Esse transporte é intimamente associado aos microtúbulos e aos motores de dineína (38). Em um trabalho publicado por Suikkanen et al. em 2003 (38) fica evidente a associação dos capsídeos de CPV com os filamentode de tubulina. Esse trabalho mostrou também que o tratamento com nocodazol (uma droga que induz a despolarização dos filamentos de tubulina), ou com um anticorpo anti-dineína, bloqueavam o transporte e a entrada de CPV no núcleo da célula hospedeira e, conseqüentemente, a replicação do vírus. Deste modo, acredita-se que o transporte dos capsídeos recém liberados dos endossomos por motores de dineína ancorados aos microtúbulos seja um mecanismo essencial para a replicação dos parvovírus, incluindo o $\mathrm{HBoV}$, pois ele é fundamental para a entrada do vírus no núcleo celular.

O mecanismo de transporte dos parvovirus através da membrana nuclear ainda não é completamente entendido, mas acredita-se que envolva o complexo do poro nuclear (11). A proteína VP1 desses vírus apresenta em sua região exclusiva (não presente em VP2) sítios de endereçamento nuclear denominados NLS, que são expostos na região externa do capsídeo 
viral. Esses sítios, localizados entre os resíduos 4 e 13 dessa proteína em CPV, são essenciais para a entrada desse vírus no núcleo. Mutações nesses sítios inibem a replicação de CPV, e esses resíduos quando conjugados ao BSA induzem o transporte dessa molécula para o núcleo da célula transfectada (36). Nenhum trabalho até o momento analisou o transporte nuclear de HBoV.

Uma vez no núcleo da célula infectada, ocorre a liberação do genoma viral constituído de DNA de fita simples. O mecanismo de como essa liberação ocorre é pouco entendido para os parvovirus. Particularmente, para $\mathrm{HBoV}$, nada foi estudado ainda. Muitos membros da família Parvoviridae, incluindo B19, CPV, MVM e AAV-2, têm 20 a 30 nucleotídeos da região 5' do genoma viral expostos para o lado de fora dos capsídeos (11). Esse DNA extracapsídeo exposto dentro do núcleo da célula hospedeira pode servir como molde para o início da replicação do DNA viral por uma DNA polimerase celular. Essa ligação à maquinaria de replicação celular poderia remover o DNA viral de seu capsídeo sem desmontá-lo ou poderia, ainda, induzir seu desmanche (11). Entretanto, essas teorias precisam ser corroboradas por evidências científicas. O que se sabe até o momento é que essas regiões expostas do DNA são essenciais para a replicação dos parvovírus. Além disso, outros mecanismos que promovam o desmantelamento do capsídeo viral dentro do núcleo não podem ser descartados.

A replicação do genoma dos parvovírus é um evento muito particular na biologia, pois seu material genético (uma molécula de DNA de fita simples) é composto por uma estrutura não usual na natureza. Por essa particularidade, acredita-se que o mecanismo de replicação do DNA desses vírus seja conservado para todos os membros dessa família, com apenas algumas características específicas para cada espécie de parvovírus.

Os membros da família Parvoviridae não codificam uma DNA polimerase viral. Desse modo, esses vírus precisam utilizar uma DNA polimerase celular para replicar seu material genético (24). Todos os parvovírus precisam alcançar o núcleo e esperar que a célula hospedeira entre em fase S do ciclo celular para duplicar seu DNA (24). Por isso, os membros dessa família se replicam mais eficientemente em células que possuam um alto "turnover" replicativo, como células dos epitélios digestivo e respiratório e células precursoras na medula óssea (12).

O DNA dos parvovirus possui em suas extremidades estruturas em "hairpin" essenciais para sua replicação. Essas estruturas formadas pela presença de regiões palindrômicas no DNA viral (FIGURA 3) funcionam como iniciadores da replicação viral, fornecendo a extremidade 3'-OH livre necessária para a ligação da DNA polimerase celular e início da replicação (24). Uma particularidade da replicação do DNA dos parvovírus é que por 
ela começar a partir de uma molécula de DNA de fita simples, não há a formação da fita “lagging” ou atrasada que normalmente ocorre durante a replicação de uma molécula de DNA de fita dupla (12).

A replicação do DNA dos parvovírus acontece por um mecanismo quase circular de rolamento dos “harpins” que leva a formação de uma série de intermediários em duplex e em concatâmeros (FIGURA 6). No núcleo da célula hospedeira, o “harpin” da extremidade 3’ do DNA viral nu funciona como iniciador para a síntese da fita filha pela DNA polimerase celular. A síntese da fita filha procede normalmente até o encontro com a extremidade em “hairpin” do lado 5’ da fita mãe. Acredita-se que a seguir ocorra a fusão por uma DNA ligase, formando uma estrutura quase que circular de DNA de fita dupla (12). Essa estrutura é clivada por uma endonuclease viral, muito provavelmente NS1, o que fornece um novo sítio 3’-OH livre na fita filha. Esse sítio serve como iniciador e a síntese da fita filha começa novamente, levando a reformação das estruturas em "hairpin” nessa extremidade do genoma. A síntese de DNA continua de modo que agora a fita filha passa a servir como molde para a síntese de uma fita igual à fita mãe viral. Com o avanço da DNA polimerase, a fita mãe original se abre e se estende, servindo novamente como molde para outra fita filha até que a enzima alcance a estrutura em “hairpin” do lado 3' do genoma viral. Esse processo leva a formação de um grande concatâmero em quase círculo que é então clivado pela endonuclease viral. Os produtos dessa clivagem podem servir como molde para reinício do processo ou serem encapsidados para a formação de novos vírus (12) (FIGURA 6).

Apenas fitas simples de DNA de parvovírus são encapsidadas. Alguns vírus dessa família encapsidam apenas fitas de DNA com polaridade negativa, como o MVM (12). Entretanto, a maioria dos vírus dessa família encapsidam isoladamente ambas as fitas do DNA em proporções que variam de vírus para vírus (11). Ainda não se sabe qual a proporção de fitas de polaridade negativa e positiva que $\mathrm{HBoV}$ encapsida, mas acredita-se que como os outros membros do gênero Bocavirus, HBoV encapside ambas as fitas de DNA isoladamente (23). 


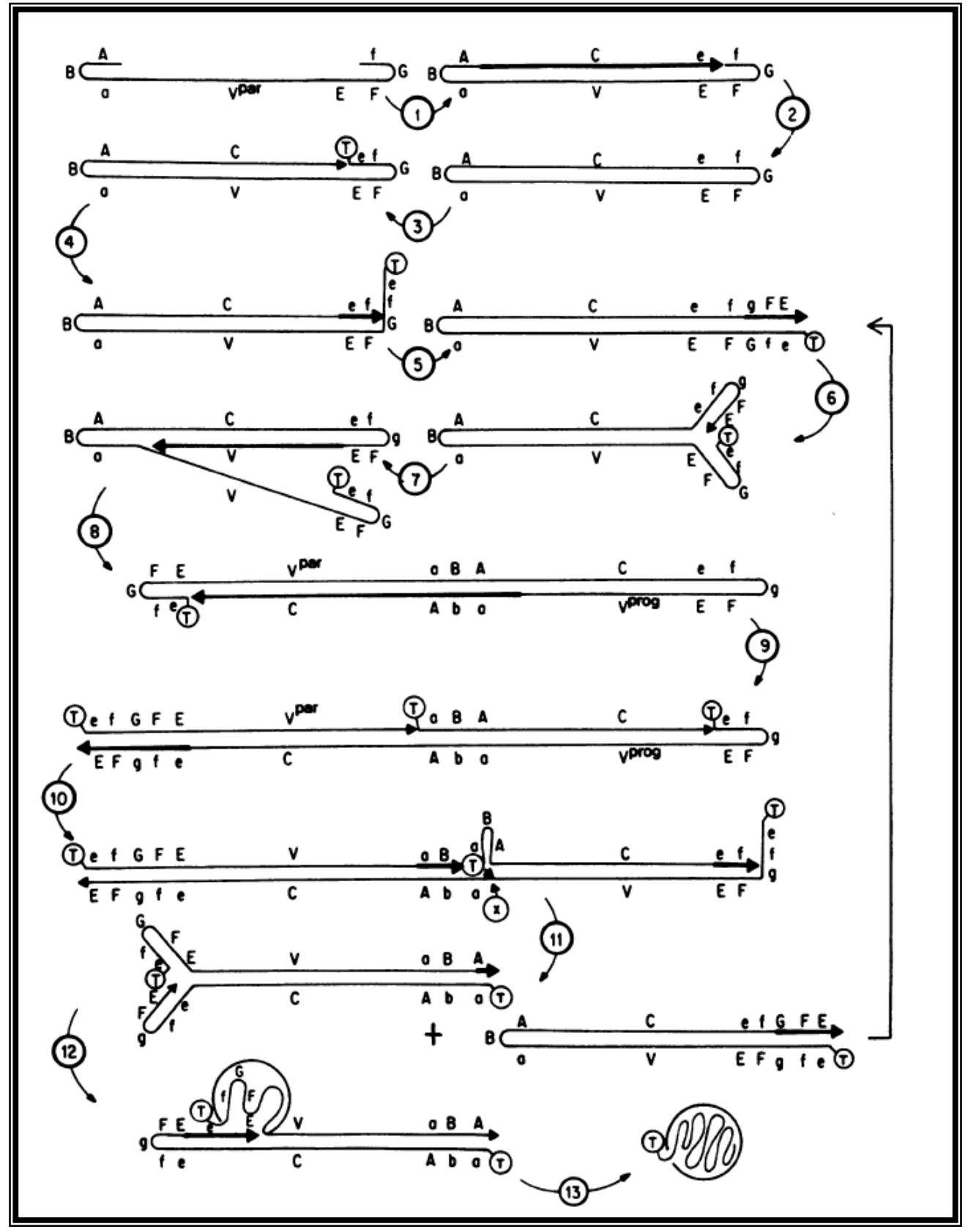

FIGURA 6. Modelo de replicação do vírus MVM. No núcleo da célula hospedeira a região Aba serve como "primer” para a síntese da fita filha por uma DNA polimerase celular (1). A síntese prossegue até o encontro com a extremidade FGf, quando ocorre a ligação por uma DNA ligase celular (2). Essa região de junção é reconhecida e clivada por uma endonuclease de restrição viral (NS1) (3), fornecendo um novo sítio iniciador para a síntese nucleotídica (4 e 5). Essa síntese leva a re-formação de estruturas em "harpin” nessa extremidade (6) e faz com que a fita filha passe a servir como molde para a síntese de uma fita igual à fita mãe viral (7). Com o avanço da DNA polimerase, a fita mãe original se abre e se estende, servindo novamente como molde para outra fita filha levando a formação de um grande concatâmero (8). Esse concatâmero é então clivado pela endonuclease viral (9) e os produtos podem servir como molde para reinício do processo (10 e 11) ou serem encapsidados para a formação de novos vírus (12 e 13) Abreviações: ABa, região palindrômica na extremidade 3' do genoma viral (fita mãe). FGf, região palindrômica na extremidade 5' do genoma viral (fita mãe). T sítio de clivagem por uma endonuclease que é na maioria dos casos de origem viral (NS1). V, é a fita viral de DNA, ou fita mãe ( $\mathrm{V}^{\text {par }}$ - fita parental, $\mathrm{V}^{\text {prog }}$ - fita da progênie viral). C, fita complementar e X é um possível sítio de ação de uma topoisomerase. Adaptado de Berns 1990 (12). 
Embora os mecanismos de transcrição e tradução de proteínas para HBoV ainda não sejam conhecidos, eles não devem ser muito diferentes dos outros membros da família. Resumidamente, os RNAs virais produzidos no núcleo por uma RNA polimerase celular são exportados para o citoplasma, onde são traduzidos em proteínas pelos ribossomos celulares (11) (FIGURA 7). A transcrição de RNA mensageiro (mRNA) e conseqüente produção de proteínas virais acontece sem que a célula hospedeira tenha entrado na fase $S$ do ciclo celular (39), indicando que esse fenômeno pode acontecer antes da replicação do genoma viral. Provavelmente, já existem capsídeos prontos, pré-formados, por ocasião da formação de genomas virais (39).

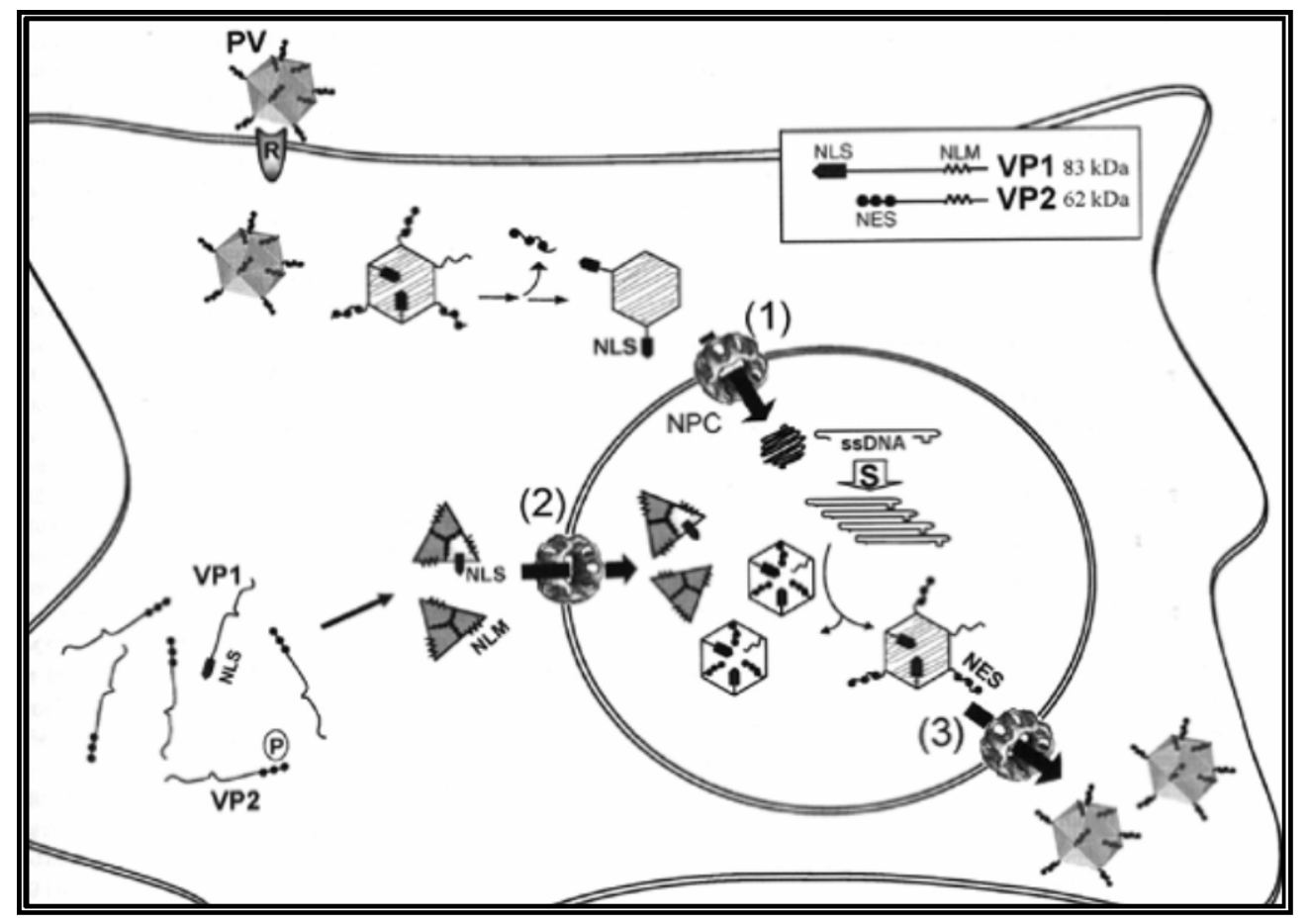

FIGURA 7. Esquema mostrando o transporte nuclear do capsídeo e de suas proteínas durante o ciclo replicativo de um parvovirus. A entrada dos capsídeos virais no núcleo durante o início da infecção (1) e dos capsômeros traduzidos no citoplasma (2) envolve o reconhecimento de sítios de localização nuclear (NLS) presente na região exclusiva de VP1. A saída do núcleo dos "virions" montados (3) envolve o reconhecimento de regiões de exportação nuclear (NES) fosforiladas na porção N terminal de VP2. Adaptado de Fields Virology (11).

Os mecanismos de transcrição e tradução das proteínas dos parvovirus são complexos e ainda não completamente entendidos. Esses mecanismos envolvem a utilização de múltiplos promotores, "splicing", "splicing alternativo", sítios aceptores, códons de iniciação não usuais e clivagem proteolítica (12). Um trabalho recente revelou que há uma baixíssima variação no padrão de códons usados entre diversas linhagens de HBoV (40). 
O controle transcricional e traducional dos parvovirus é um campo fascinante, com mais perguntas que respostas. Aparentemente, existe uma regulação temporal da expressão gênica durante o ciclo infeccioso desses vírus (39). Em MVM, a expressão da proteína NS1 acontece relativamente cedo e é indispensável para a trans-ativação da transcrição do promotor p38, responsável pela expressão das proteínas do capsídeo (41). Além disso, também foi documentada a inibição da expressão gênica celular por alguns membros da família Parvoviridae. Em AAV, a expressão de uma proteína não estrutural denomina rep possuí efeito inibitório em promotores de origem não viral (42).

Depois de formadas no citoplasma, as proteínas do capsídeo (VP1 e VP2 para HBoV) se agrupam em capsômeros e são importados para o núcleo através de uma mecanismo provavelmente semelhante ao que ocorre com o vírus inteiro no início do ciclo replicativo. Os sítios de localização nuclear (NLS) presentes na região exclusiva de VP1 são essenciais nesse processo (11). No núcleo celular esses capsômeros se ligam ao DNA viral de fita simples, formando a progênie viral. Esses vírus recém formados são, então, exportados para o citoplasma através de um mecanismo que envolve a fosforilação de uma seqüência de exportação nuclear (NES) presente na região N terminal de VP2 (FIGURA 7). A liberação da progênie viral pode se dar por exocitose ou lise celular, dependendo da espécie viral (11). Esses mecanismos ainda não foram estudados para $\mathrm{HBoV}$.

\section{4-) Patogenicidade de $\mathrm{HBoV}$}

Já existem mais de 100 estudos relatando a ocorrência de HBoV, principalmente em crianças, no mundo todo. Entretanto, em nenhum deles ficou comprovada a real associação entre $\mathrm{HBoV}$ e doenças no homem. Grande parte dessa dificuldade vem do fato que não é possível aplicar os postulados de Koch a $\mathrm{HBoV}$, pois até agora não existe modelo para a infecção por esse vírus e ele não pode ser propagado em nenhuma linhagem celular corriqueiramente usadas nos laboratórios de pesquisa ao redor do mundo (23). Os estudos publicados até o momento relatam a freqüência e às vezes a carga viral desse vírus em pacientes ao redor do mundo, sugerindo a existência de uma possível associação entre HBoV e diversas patologias humanas. Ainda não se conhece as rotas de infecção, os sítios replicativos e os mecanismos patogênicos de HBoV. Acredita-se que a infecção aconteça pela via inalatória, por inoculação via fômites ou pela via fecal-oral (23). Entretanto, ainda são necessários estudos para detalhar essas vias. 
Estudos que analisaram a presença de resposta imune específica contra $\mathrm{HBoV}$ em adultos saudáveis mostram que esse vírus é altamente prevalente em humanos (43). Kahn et al. (44), mostraram que 85\% das crianças com mais de 48 meses já tinham entrado em contato com $\mathrm{HBoV}$ e haviam se tornado soropositivas para esse vírus (44). Esses resultados sugerem que a disseminação de $\mathrm{HBoV}$ é muito eficiente.

\subsection{1-) Bocavirus humano e doenças do trato respiratório.}

O HBoV é freqüentemente encontrado em amostras de pacientes com sintomas de infecção do trato respiratório (IRA) (2, 16, 17, 45). Entretanto, diversos fatores dificultam o estabelecimento de uma relação causal entre a presença de $\mathrm{HBoV}$ e os sintomas clínicos observados. Em primeiro lugar, $\mathrm{HBoV}$ pode se manter persistentemente, sem se replicar (ou fazendo-o a uma taxa baixíssima), por longos períodos de tempo no homem, do mesmo modo que outros parvovírus humanos, como o B19, PARV4 e AAV (46). Em segundo lugar, HBoV é comumente detectado em associação com outros vírus respiratórios com a patogenicidade já estabelecida (47-49). Um trabalho publicado por Esposito et al. (2008) (48) mostrou que a taxa de coinfecção de $\mathrm{HBoV}$ com outros vírus é significantemente maior que a taxa de coinfecção pelos mesmos vírus em pacientes sem HBoV. Além disso, esses autores sugeriram que, aparentemente, o papel da infecção com HBoV sozinho é marginal em crianças atendidas em unidades de emergência com doença respiratória aguda. A relevância clínica e sócioeconômica de $\mathrm{HBoV}$ só foi notada quando esse vírus estava em associação com outros vírus respiratórios, como influenza A e B (Flu A e B), vírus sincicial respiratório (RSV) e rinovirus (HRV).

Juntos, esses fatores sugerem que a detecção de $\mathrm{HBoV}$ no trato respiratório possa simplesmente refletir persistência assintomática. Além disso, pode ser hipotetizado que HBoV é reativado ou produz uma superinfecção transiente e talvez assintomática na presença de outros patógenos virais no trato respiratório (23). Entretanto, diversos estudos vêm mostrando evidências de que $\mathrm{HBoV}$ pode estar significantemente associado a doenças do trato respiratório superior e inferior, principalmente em crianças. As principais evidências foram obtidas de estudos que incluíam grupos controles de pacientes assintomáticos em suas análises (5, 7, 17, 18, 50). Nesses estudos, a prevalência de HBoV mostrou-se significantemente maior em pacientes com IRA do que em pacientes sem sintomas.

O estudo de Manning et al. (2006) (50), realizado com amostras respiratórias de 574 pacientes escoceses, detectou $\mathrm{HBoV}$ em aproximadamente $15 \%$ daqueles com sintomas de infecção do trato respiratório inferior, em $6 \%$ dos pacientes com sintomas do trato respiratório 
superior e em apenas 1\% dos pacientes sem sintomas de infecção do trato respiratório. Já Kesebir et al. (2006) (5) detectaram HBoV em 22 de 425 crianças com IRA nos Estados Unidos, mas foi incapaz de detectar esse vírus em 96 crianças sem sintomas. Dados semelhantes foram observados por Allander et al. (2007) (18) em crianças finlandesas e por Maggi et al. (2007) (7) em crianças italianas. Esses autores diagnosticaram HBoV em 19\% e 4,5\% das crianças finlandesas e italinas com IRA, respectivamente. Interessantemente, nesses estudos HBoV não foi detectado em crianças assintomáticas.

Em um importante estudo coordenado pelo "Centers for Disease Control and Prevention” (CDC) e publicado por Fry et al. em 2007 (17), foram analisados 1.960 pacientes tailandeses. Desses, 1.168 tinham pneumonia adquirida na comunidade, 512 tinham sintomas de gripe e 280 não apresentavam sintomas de IRA. HBoV foi detectado em apenas 3 indivíduos assintomáticos (1\%), mas foi detectado em 3,9\% dos pacientes com sintomas de gripe e em 4,5\% dos pacientes com pneumonia. Além disso, a prevalência de HBoV em crianças menores de 5 anos foi de 12\% naquelas com pneumonia e de apenas $2 \%$ naquelas sem sintomas de IRA. HBoV foi o terceiro vírus mais freqüentemente detectado em crianças com diagnóstico de pneumonia.

Outro dado que indica que $\mathrm{HBoV}$ está significantemente associado a IRA foi obtido em estudos que determinaram a carga viral em pacientes com e sem sintomas (51, 52). Nesses estudos, a carga viral de $\mathrm{HBoV}$ foi alta apenas em pacientes sintomáticos. Além disso, Allander et al. (2007) mostraram que em pacientes hospitalizados por chiado há uma ligação entre a ocorrência de HBoV no sangue e o episódio infeccioso agudo. O desaparecimento dos sintomas coincide com a diminuição dos níveis de viremia.

Com relação ao papel das coinfecções na biologia do HBoV, muito pouco se sabe e mais estudos são necessários. Estudo recentes mostram que a carga viral de HBoV é mais alta em pacientes com sintomas de IRA e sem nenhuma coinfecção $(18,51)$, o que é tido como indício de associação entre $\mathrm{HBoV}$ e doença respiratória em humanos. Tomados em conjunto os dados disponíveis indicam que uma carga viral alta e viremia por HBoV são associados com sintomas de infecção do trato respiratório, enquanto que detecção desse vírus em baixa carga e em conjunto com outros patógenos virais do trato respiratório, apontam para a possibilidade de persistência de $\mathrm{HBoV}$ no trato respiratório no homem. De fato, Regamery et al. (2008) (53) mostraram que esse vírus pode ser detectado até três semanas após a sua detecção inicial.

Os sintomas respiratórios que mais freqüentemente têm sido associados à infecção por HBoV são: chiado (3, 18, 54-57), crupe (58), tosse, rinorréia e febre (59, 60). Entre os 
diagnósticos clínicos dos pacientes com $\mathrm{HBoV}$, os mais comuns têm sido: infecção das vias aéreas superiores (IVAS) (59, 60), bronquiolite (8, 18, 51), pneumonia (6, 17, 57, 61), bronquite (62) e exacerbação aguda de asma (63). Os sintomas, em geral, duram de uma a duas semanas (18, 53, 64). Entretanto, Monteny et al. (2007) (65) relataram infecção por HBoV com curso prolongado de febre.

Embora as vias de infecção e os mecanismos de patogenicidade de $\mathrm{HBoV}$ ainda não sejam conhecidos, alguns aspectos são conhecidos sobre outros representantes desse gênero, como CnMV e BPV. BPV também causa doença respiratória em bezerros (10). Esse vírus entra por via oral e a replicação inicial ocorre nas tonsilas e trato intestinal, de onde ele se espalha para o sangue, tecidos linfóides e epitélio respiratório (10). Esse vírus induz atrofia das microvilosidades no intestino delgado e morte por apoptose e necrose de células do tecido linfóide e células ciliadas do epitélio respiratório (10). O papel da inflamação no surgimento dos sintomas durante a infecção por $\mathrm{HBoV}$ também não é entendido. Um trabalho recente (66) mostrou que citocinas de ambos os padrões, Th1 e Th2, estavam aumentadas em crianças infectadas com HBoV e com bronquiolite, mas não foi observado nenhum padrão polarizado da resposta imune.

\subsection{2-) Bocavirus humano e doenças do trato digestório.}

Em 2007, Vicente et al. (20) ao investigar a prevalência de HBoV em crianças com sintomas respiratórios na região Basca da Espanha observaram que duas delas também tinham diarréia. Baseando-se no fato de que BPV causa diarréia em bezerros, esses autores investigaram a presença de $\mathrm{HBoV}$ nas fezes dessas duas crianças. Interessantemente, HBoV foi encontrado em ambas as crianças, e nenhum outro agente causador de diarréia foi encontrado, sugerindo que esse vírus cause gastroenterites em crianças. Com esses dados em mãos os autores investigaram a prevalência de $\mathrm{HBoV}$ nas fezes de 527 crianças com gastroenterites e observaram que em 9,1\% o vírus foi detectado. Com isso, os autores levantaram a hipótese de que $\mathrm{HBoV}$ pode estar associado a quadros de gastroenterites em crianças e que a excreção nas fezes pode ter um papel importante na transmissão desse vírus.

A partir desse estudo, vários trabalhos têm relatando a presença de $\mathrm{HBoV}$ nas fezes de crianças ao redor do mundo (19, 67-69) em freqüências variando de 0,8\% a 4,6\% (67, 69). Entretanto, muitos desses trabalhos não confirmam o que foi sugerido por Vicente et al. (2007) e indicam que HBoV aparentemente não possui um papel causal em gastroenterites em crianças (67-69). 


\subsection{3-) Bocavirus e doença sistêmica, lesões da pele, otite média aguda e inflamação tonsilar.}

Diversos membros da família Parvoviridae possuem a capacidade de causar viremia, sendo freqüentemente detectados no sangue. Entretanto, pouco se sabe sobre os mecanismos e o tropismo tecidual de HBoV. Um estudo realizado por Kantola et al., 2008 (70) utilizando o soro pareado de 117 crianças com chiado mostrou que a infecção respiratória por HBoV são sistêmicas, levam a uma resposta de células B e pode ser diagnosticada sorologicamente. Além disso, os autores mostraram que o diagnóstico sorológico de $\mathrm{HBoV}$ é correlacionado com altas cargas virais nos lavados nasofaríngeos (LFNs) e com viremia. Nesse estudo, 49\% das crianças positivas para $\mathrm{HBoV}$ por PCR tinham anticorpos IgM anti-HBoV e 73\% tinham anticorpos IgG. Todos os pacientes com alta carga de $\mathrm{HBoV}$ nos LFNs tinham altos títulos de IgM, PCR positivo para esse vírus no sangue (indicando viremia) e não apresentavam infecção com nenhum outro vírus respiratório. Além disso, um trabalho publicado por Allander et al. 2007 (18) também detectou de maneira freqüente o DNA de HBoV em amostras de soro de pacientes com chiado agudo.

Portanto, hoje se sabe que $\mathrm{HBoV}$ pode ser detectado nas secreções respiratórias, nas fezes e no sangue, mas ainda não se conhece quais são as células infectadas, quais os nichos replicativos desse vírus e se ele pode infectar outros tecidos. Alguns trabalhos detectaram HBoV em pacientes com erupções da pele, mas nenhuma relação causal foi observada $(4,65$, 71).

Em um trabalho recente, Longtin et al. 2008 (6) observaram uma alta freqüência de $\mathrm{HBoV}$ (aproximadamente 45\%) em LFNs de pacientes controle, que não apresentavam sintomas de infecção do trato respiratório. Esses pacientes (que eram na sua maioria crianças) não tinham sintomas respiratórios, mas estavam internados para remoção das adenóides e tonsilas, pois eles apresentavam complicações clínicas devido à inflamação desses tecidos, tais como apnéia noturna, otite média e tonsilite crônica. Isso sugere uma ligação direta entre esse vírus e a inflamação desses tecidos. Para testar essa hipótese, Lu et al., 2008 (21) analisaram as tonsilas nasofaríngeas ou adenóides e as tonsilas da língua e do palato de 164 crianças submetidas à adenoidectomias e tonsilectomias de rotina. Eles encontraram $\mathrm{HBoV}$ nos linfócitos tonsilares de 53 crianças, sugerindo que $\mathrm{HBoV}$ pode estabelecer infecção nos linfócitos de mucosa e assim contribuir para a hiperplasia tonsilar em crianças jovens. Talvez, assim como em BPV, as tonsilas sirvam como um dos sítios primários de replicação de $\mathrm{HBoV}$. 


\section{5-) Diagnóstico, tratamento e prevenção.}

O diagnóstico laboratorial de $\mathrm{HBoV}$ tem sido realizado predominantemente em lavados e "swabs" nasofaríngeos por métodos moleculares, baseados na metodologia de PCR, uma vez que métodos baseados em cultura viral, modelo animal e detecção de antígenos por anticorpos ainda não foram desenvolvidos ou, quando foram, não se tornaram disponíveis comercialmente $(1,29,52,72,73)$. Até o momento, a região do genoma mais usada para o desenho dos iniciadores é a que codifica o gene NP1 (1). Para estudos filogenéticos ou de variabilidade, a região codificadora de VP1 e VP2 é mais adequada para o desenho de iniciadores, visto que essa região do genoma possui maior variabilidade (28).

Diversas metodologias de PCR em tempo real têm sido utilizadas para a detecção desse vírus, incluindo aquelas que utilizam o "Sybr Green" (uma molécula intercalante de DNA, que se liga em DNA de fita dupla formado durante a reação de PCR) e aquelas que utilizam sondas marcadas com fluoróforos específicos (como FAM ou JOE) que se ligam por pareamento de bases entre a região de ligação dos dois iniciadores utilizados durante a PCR (sistema Taqman - Applied Biosystems) (29, 52, 72, 73). Por ser um vírus recentemente descoberto, muito pouco se sabe sobre a sua biologia e seus mecanismos de transmissão. Conseqüentemente, não existem medidas de tratamento e prevenção disponíveis.

Resumidamente, o bocavirus humano é um vírus recentemente descoberto que aparentemente está relacionado a doenças respiratórias predominantemente na infância. Ele vem sendo detectado em várias regiões do mundo, com freqüência que varia entre 1,5\% a 19\%, dependendo da faixa etária e das características clínicas dos pacientes analisados. Aparentemente, esse vírus está associado a quadros de bronquiolite, pneumonia, crupe, bronquite obstrutiva e exacerbação de asma, principalmente em crianças menores de dois anos. Entretanto, a relação causal entre $\mathrm{HBoV}$ e os quadros clínicos descritos acima ainda não foi confirmada. A alta freqüência de co-infecção com outros vírus respiratórios conhecidos, como HRSV, HRV e FLU soma-se à ausência de modelos animais e de evidências experimentais, para por em dúvida essa associação. Pouca se sabe sobre a biologia desse vírus, incluindo sua variabilidade, rotas de transmissão, sítios replicativos e mecanismos de patogenicidade. No Brasil, nenhum estudo sistemático sobre a presença desse vírus no trato respiratório foi feito. Apenas dois trabalhos do nosso grupo de pesquisa relatam a presença desse vírus em vias aéreas de pacientes com IRA em nosso país (45, 74). Por isso, a realização de um estudo sistemático, analisando a prevalência, carga viral e diversidade de HBoV em nossa região encontra-se justificado. 


\section{OBJETIVOS}

\section{1-) Objetivo Geral.}

O objetivo geral deste projeto foi detectar e seqüenciar o genoma de $\mathrm{HBoV}$ em amostras de secreção respiratória coletadas de pacientes atendidos em unidades de saúde de Ribeirão Preto com sintomas de IRA, verificando a existência de relação entre os quadros clínicos e a carga viral.

\section{2-) Objetivos Específicos.}

- Determinar a freqüência de detecção de HBoV em crianças e adultos com IRA e assintomáticos atendidos durante os anos de 2005, 2006 e 2007 no Hospital das Clínicas de Ribeirão Preto da Faculdade de Medicina da USP (HCFMRPUSP) e no Hospital Santa Lydia, ambos na cidade de Ribeirão Preto.

- Determinar a freqüência de co-infecção por outros vírus respiratórios conhecidos [vírus sincicial respiratório (HRSV), rinovírus (HRV), influenza (FLU), parainfluenza (HPIV), Metapneumovirus (HMPV), Adenovírus (HAdV) e coronavirus (HCoV)] nos pacientes positivos para $\mathrm{HBoV}$.

- Determinar a carga viral de $\mathrm{HBoV}$ nos lavados nasofaringeos por PCR em tempo real utilizando o sistema “Taqman” (Applied Biosystems ${ }^{\circledR}$, Foster City, CA).

- Determinar a presença de indícios de replicação de HBoV no LNFs dos pacientes estudados

- Sequenciar o genoma completo de cepas de HBoV de pacientes atendidos em Ribeirão Preto e em Salvador, BA.

- Estudar a filogenia de genoma completo dessas cepas de $\mathrm{HBoV}$ e de seqüências depositadas no GenBank.

- Verificar a existência de mutações e possíveis associações com quadros clínicos, distribuição geográfica e carga viral.

- Clonar e expressar uma das proteínas do capsídeo de HBoV. 
CONCLUSÕES 


\section{CONCLUSÕES}

- HBoV circula em crianças e adultos com sintomas de infecção do trato respiratório no Brasil.

- A freqüência de detecção de HBoV é maior em crianças menores de cinco anos do que na população de pacientes maiores de cinco anos com sintomas de infecção do trato respiratório.

- A freqüência de $\mathrm{HBoV}$ varia de ano para ano.

- $\mathrm{HBoV}$ circula durante quase todos os meses do ano.

- A sazonalidade de $\mathrm{HBoV}$ não está associada com os meses de maior distribuição de HRSV.

- A freqüência de diarréia é maior em pacientes com $\mathrm{HBoV}$ do que em pacientes com IRA de outras etiologias.

- A freqüência de co-infecção entre HBoV e os outros vírus respiratórios é alta.

- A carga viral de HBoV por PCR em tempo real é maior em pacientes com infecção exclusiva por esse vírus do que em pacientes com co-infecção.

- A normalização por $\beta$-actina é importante para uma acurada quantificação desse vírus nos lavados nasofaríngeos.

- A freqüência de diarréia é maior nos pacientes com infecção apenas por HBoV do que nos pacientes com co-infecção.

- Existe associação entre alta carga viral e diarréia nos pacientes menores de cinco anos com sintomas de IRA.

- O seqüenciamento do genoma completo mostrou que a diversidade genética entre HBoV é baixa.

- É possível clonar e expressar a proteína VP2 do capsídeo viral de HBoV em $S$. cerevisiae PEP2 (Y258) 
Conforme o "International Committee of Medical Journal Editors" (Vancouver Style) - Grupo de Vancouver. 


\section{REFERÊNCIAS}

1. Allander T, Tammi MT, Eriksson M, Bjerkner A, Tiveljung-Lindell A, Andersson B. Cloning of a human parvovirus by molecular screening of respiratory tract samples. Proc Natl Acad Sci U S A. 2005 Sep 6;102(36):12891-6.

2. Bastien N, Chui N, Robinson JL, Lee BE, Dust K, Hart L, et al. Detection of human bocavirus in Canadian children in a 1-year study. J Clin Microbiol. 2007 Feb;45(2):610-3.

3. Chieochansin T, Samransamruajkit R, Chutinimitkul S, Payungporn S, Hiranras T, Theamboonlers A, et al. Human bocavirus (HBoV) in Thailand: clinical manifestations in a hospitalized pediatric patient and molecular virus characterization. J Infect. 2008 Feb;56(2):137-42.

4. Chung JY, Han TH, Kim CK, Kim SW. Bocavirus infection in hospitalized children, South Korea. Emerg Infect Dis. 2006 Aug;12(8):1254-6.

5. Kesebir D, Vazquez M, Weibel C, Shapiro ED, Ferguson D, Landry ML, et al. Human bocavirus infection in young children in the United States: molecular epidemiological profile and clinical characteristics of a newly emerging respiratory virus. J Infect Dis. 2006 Nov 1;194(9):1276-82.

6. Longtin J, Bastien M, Gilca R, Leblanc E, de Serres G, Bergeron MG, et al. Human bocavirus infections in hospitalized children and adults. Emerg Infect Dis. 2008 Feb;14(2):217-21.

7. Maggi F, Andreoli E, Pifferi M, Meschi S, Rocchi J, Bendinelli M. Human bocavirus in Italian patients with respiratory diseases. J Clin Virol. 2007 Apr;38(4):321-5.

8. Simon A, Groneck P, Kupfer B, Kaiser R, Plum G, Tillmann RL, et al. Detection of bocavirus DNA in nasopharyngeal aspirates of a child with bronchiolitis. J Infect. 2007 Mar;54(3):e125-7.

9. ICTVdB. Parvoviridae. International Committee on Taxonomy of Viruses; 2008 [updated 2008; cited 2009]; Available from: http://www.ncbi.nlm.nih.gov/ICTVdb/Ictv/index.htm.

10. Manteufel J, Truyen U. Animal Bocaviruses: A Brief Review. Intervirology. 2008;51(5):328-34.

11. Berns K, Parrish CR. Parvoviridae. In: Knipe DM, Howley PM, editors. Fields Virology. Philadelphia, NY: Lippincott Williams \& Wilkins; 2007. p. 2437.

12. Berns KI. Parvovirus replication. Microbiol Rev. 1990 Sep;54(3):316-29.

13. Brieu N, Gay B, Segondy M, Foulongne V. Electron microscopy observation of human bocavirus (HBoV) in nasopharyngeal samples from $\mathrm{HBoV}$-infected children. J Clin Microbiol. 2007 Oct;45(10):3419-20. 
14. Carmichael LE, Schlafer DH, Hashimoto A. Pathogenicity of minute virus of canines for the canine fetus. Cornell Vet. 1991;81:151-71.

15. Carmichael LE, Schlafer DH, Hashimoto A. Minute virus of canines (canine parvovirus type-1): pathogenicity for pups and soroprevalence estimate. J Vet Diagn Invest. 1994;6:165-74.

16. Bastien N, Brandt K, Dust K, Ward D, Li Y. Human Bocavirus infection, Canada. Emerg Infect Dis. 2006 May;12(5):848-50.

17. Fry AM, Lu X, Chittaganpitch M, Peret T, Fischer J, Dowell SF, et al. Human bocavirus: a novel parvovirus epidemiologically associated with pneumonia requiring hospitalization in Thailand. J Infect Dis. 2007 Apr 1;195(7):1038-45.

18. Allander T, Jartti T, Gupta S, Niesters HG, Lehtinen P, Osterback R, et al. Human bocavirus and acute wheezing in children. Clin Infect Dis. 2007 Apr 1;44(7):904-10.

19. Albuquerque MC, Rocha LN, Benati FJ, Soares CC, Maranhao AG, Ramirez ML, et al. Human bocavirus infection in children with gastroenteritis, Brazil. Emerg Infect Dis. 2007 Nov;13(11):1756-8.

20. Vicente D, Cilla G, Montes M, Perez-Yarza EG, Perez-Trallero E. Human bocavirus, a respiratory and enteric virus. Emerg Infect Dis. 2007 Apr;13(4):636-7.

21. Lu X, Gooding LR, Erdman DD. Human bocavirus in tonsillar lymphocytes. Emerg Infect Dis. 2008 Aug;14(8):1332-4.

22. Fryer JF, Delwart E, Hecht FM, Bernardin F, Jones MS, Shah N, et al. Frequent detection of the parvoviruses, PARV4 and PARV5, in plasma from blood donors and symptomatic individuals. Transfusion. 2007 Jun;47(6):1054-61.

23. Schildgen O, Muller A, Allander T, Mackay IM, Volz S, Kupfer B, et al. Human bocavirus: passenger or pathogen in acute respiratory tract infections? Clin Microbiol Rev. 2008 Apr;21(2):291-304, table of contents.

24. Tattersall P, Ward DC. Rolling hairpin model for replication of parvovirus and linear chromosomal DNA. Nature. 1976 Sep 9;263(5573):106-9.

25. Zadori Z, Szelei J, Lacoste MC, Li Y, Gariepy S, Raymond P, et al. A viral phospholipase A2 is required for parvovirus infectivity. Dev Cell. 2001 Aug;1(2):291-302.

26. Zhi N, Mills IP, Lu J, Wong S, Filippone C, Brown KE. Molecular and functional analyses of a human parvovirus B19 infectious clone demonstrates essential roles for NS1, VP1, and the 11-kilodalton protein in virus replication and infectivity. J Virol. 2006 Jun;80(12):5941-50.

27. Lederman M, Patton JT, Stout ER, Bates RC. Virally coded noncapsid protein associated with bovine parvovirus infection. J Virol. 1984 Feb;49(2):315-8. 
28. Chieochansin T, Chutinimitkul S, Payungporn S, Hiranras T, Samransamruajkit R, Theamboolers A, et al. Complete coding sequences and phylogenetic analysis of Human Bocavirus (HBoV). Virus Res. 2007 Oct;129(1):54-7.

29. Neske F, Blessing K, Tollmann F, Schubert J, Rethwilm A, Kreth HW, et al. Realtime PCR for diagnosis of human bocavirus infections and phylogenetic analysis. J Clin Microbiol. 2007 Jul;45(7):2116-22.

30. Lin F, Hou JY, Zheng MQ, Wu F, Zeng AP, Li H, et al. [Characterization of the cytopathic effect in human bronchial epithelial cell after Human Bocavirus Infection (HBoV)]. Zhonghua Shi Yan He Lin Chuang Bing Du Xue Za Zhi. 2008 Apr;22(2):107-9.

31. Brown KE, Anderson SM, Young NS. Erythrocyte P antigen: cellular receptor for B19 parvovirus. Science. 1993 Oct 1;262(5130):114-7.

32. Nam HJ, Gurda-Whitaker B, Gan WY, Ilaria S, McKenna R, Mehta P, et al. Identification of the sialic acid structures recognized by minute virus of mice and the role of binding affinity in virulence adaptation. J Biol Chem. 2006 Sep 1;281(35):25670-7.

33. Parker JS, Murphy WJ, Wang D, O'Brien SJ, Parrish CR. Canine and feline parvoviruses can use human or feline transferrin receptors to bind, enter, and infect cells. $\mathrm{J}$ Virol. 2001 Apr;75(8):3896-902.

34. Blackburn SD, Cline SE, Hemming JP, Johnson FB. Attachment of bovine parvovirus to O-linked alpha 2,3 neuraminic acid on glycophorin A. Arch Virol. 2005 Jul;150(7):147784.

35. Parker JS, Parrish CR. Cellular uptake and infection by canine parvovirus involves rapid dynamin-regulated clathrin-mediated endocytosis, followed by slower intracellular trafficking. J Virol. 2000 Feb;74(4):1919-30.

36. Vihinen-Ranta M, Wang D, Weichert WS, Parrish CR. The VP1 N-terminal sequence of canine parvovirus affects nuclear transport of capsids and efficient cell infection. J Virol. 2002 Feb;76(4):1884-91.

37. Qu XW, Liu WP, Qi ZY, Duan ZJ, Zheng LS, Kuang ZZ, et al. Phospholipase A2-like activity of human bocavirus VP1 unique region. Biochem Biophys Res Commun. 2008 Jan 4;365(1):158-63.

38. Suikkanen S, Antila M, Jaatinen A, Vihinen-Ranta M, Vuento M. Release of canine parvovirus from endocytic vesicles. Virology. 2003 Nov 25;316(2):267-80.

39. Clemens KE, Pintel DJ. The two transcription units of the autonomous parvovirus minute virus of mice are transcribed in a temporal order. J Virol. 1988 Apr;62(4):1448-51.

40. Zhao S, Zhang Q, Liu X, Wang X, Zhang H, Wu Y, et al. Analysis of synonymous codon usage in 11 human bocavirus isolates. Biosystems. 2008 Jun;92(3):207-14.

41. Doerig C, Hirt B, Beard P, Antonietti JP. Minute virus of mice non-structural protein NS-1 is necessary and sufficient for trans-activation of the viral P39 promoter. J Gen Virol. 1988 Oct;69 ( Pt 10):2563-73. 
42. Tratschin JD, Tal J, Carter BJ. Negative and positive regulation in trans of gene expression from adeno-associated virus vectors in mammalian cells by a viral rep gene product. Mol Cell Biol. 1986 Aug;6(8):2884-94.

43. Lindner J, Zehentmeier S, Franssila R, Barabas S, Schroeder J, Deml L, et al. CD4+ T helper cell responses against human bocavirus viral protein 2 viruslike particles in healthy adults. J Infect Dis. 2008 Dec 1;198(11):1677-84.

44. Kahn JS, Kesebir D, Cotmore SF, D'Abramo A, Jr., Cosby C, Weibel C, et al. Seroepidemiology of human bocavirus defined using recombinant virus-like particles. J Infect Dis. 2008 Jul 1;198(1):41-50.

45. Gagliardi TB, Iwamoto MA, Paula FE, Proenca-Modena JL, Saranzo AM, Criado MF, et al. Human bocavirus respiratory infections in children. Epidemiol Infect. 2009 Jan 12:1-5.

46. Manning A, Willey SJ, Bell JE, Simmonds P. Comparison of tissue distribution, persistence, and molecular epidemiology of parvovirus B19 and novel human parvoviruses PARV4 and human bocavirus. J Infect Dis. 2007 May 1;195(9):1345-52.

47. Bonzel L, Tenenbaum T, Schroten H, Schildgen O, Schweitzer-Krantz S, Adams O. Frequent detection of viral coinfection in children hospitalized with acute respiratory tract infection using a real-time polymerase chain reaction. Pediatr Infect Dis J. 2008 Jul;27(7):589-94.

48. Esposito S, Bosis S, Niesters HG, Tremolati E, Sabatini C, Porta A, et al. Impact of human bocavirus on children and their families. J Clin Microbiol. 2008 Apr;46(4):1337-42.

49. Weissbrich B, Neske F, Schubert J, Tollmann F, Blath K, Blessing K, et al. Frequent detection of bocavirus DNA in German children with respiratory tract infections. BMC Infect Dis. 2006;6:109.

50. Manning A, Russell V, Eastick K, Leadbetter GH, Hallam N, Templeton K, et al. Epidemiological profile and clinical associations of human bocavirus and other human parvoviruses. J Infect Dis. 2006 Nov 1;194(9):1283-90.

51. Jacques J, Moret H, Renois F, Leveque N, Motte J, Andreoletti L. Human Bocavirus quantitative DNA detection in French children hospitalized for acute bronchiolitis. J Clin Virol. 2008 Oct;43(2):142-7.

52. Lu X, Chittaganpitch M, Olsen SJ, Mackay IM, Sloots TP, Fry AM, et al. Real-time PCR assays for detection of bocavirus in human specimens. J Clin Microbiol. 2006 Sep;44(9):3231-5.

53. Regamey N, Kaiser L, Roiha HL, Deffernez C, Kuehni CE, Latzin P, et al. Viral etiology of acute respiratory infections with cough in infancy: a community-based birth cohort study. Pediatr Infect Dis J. 2008 Feb;27(2):100-5. 
54. Bosis S, Esposito S, Niesters HG, Zuccotti GV, Marseglia G, Lanari M, et al. Role of respiratory pathogens in infants hospitalized for a first episode of wheezing and their impact on recurrences. Clin Microbiol Infect. 2008 Jul;14(7):677-84.

55. Chung JY, Han TH, Kim SW, Kim CK, Hwang ES. Detection of viruses identified recently in children with acute wheezing. J Med Virol. 2007 Aug;79(8):1238-43.

56. Smuts H, Workman L, Zar HJ. Role of human metapneumovirus, human coronavirus NL63 and human bocavirus in infants and young children with acute wheezing. J Med Virol. 2008 May;80(5):906-12.

57. Terrosi C, Fabbiani M, Cellesi C, Cusi MG. Human bocavirus detection in an atopic child affected by pneumonia associated with wheezing. J Clin Virol. 2007 Sep;40(1):43-5.

58. Rihkanen H, Ronkko E, Nieminen T, Komsi KL, Raty R, Saxen H, et al. Respiratory viruses in laryngeal croup of young children. J Pediatr. 2008 May;152(5):661-5.

59. Allander T. Human bocavirus. J Clin Virol. 2008 Jan;41(1):29-33.

60. Calvo C, Garcia-Garcia ML, Pozo F, Carvajal O, Perez-Brena P, Casas I. Clinical characteristics of human bocavirus infections compared with other respiratory viruses in Spanish children. Pediatr Infect Dis J. 2008 Aug;27(8):677-80.

61. Zhang LL, Tang LY, Xie ZD, Tan XJ, Li CS, Cui AL, et al. Human bocavirus in children suffering from acute lower respiratory tract infection in Beijing Children's Hospital. Chin Med J (Engl). 2008 Sep 5;121(17):1607-10.

62. Hengst M, Hausler M, Honnef D, Scheithauer S, Ritter K, Kleines M. [Human Bocavirus-infection (HBoV): an important cause of severe viral obstructive bronchitis in children]. Klin Padiatr. 2008 Sep-Oct;220(5):296-301.

63. Khetsuriani N, Kazerouni NN, Erdman DD, Lu X, Redd SC, Anderson LJ, et al. Prevalence of viral respiratory tract infections in children with asthma. J Allergy Clin Immunol. 2007 Feb;119(2):314-21.

64. Regamey N, Frey U, Deffernez C, Latzin P, Kaiser L. Isolation of human bocavirus from Swiss infants with respiratory infections. Pediatr Infect Dis J. 2007 Feb;26(2):177-9.

65. Monteny M, Niesters HG, Moll HA, Berger MY. Human bocavirus in febrile children, The Netherlands. Emerg Infect Dis. 2007 Jan;13(1):180-2.

66. Chung JY, Han TH, Kim JS, Kim SW, Park CG, Hwang ES. Th1 and Th2 cytokine levels in nasopharyngeal aspirates from children with human bocavirus bronchiolitis. J Clin Virol. 2008 Oct;43(2):223-5.

67. Campe H, Hartberger C, Sing A. Role of Human Bocavirus infections in outbreaks of gastroenteritis. J Clin Virol. 2008 Nov;43(3):340-2. 
68. Cheng WX, Jin Y, Duan ZJ, Xu ZQ, Qi HM, Zhang Q, et al. Human bocavirus in children hospitalized for acute gastroenteritis: a case-control study. Clin Infect Dis. 2008 Jul 15;47(2):161-7.

69. Lee JI, Chung JY, Han TH, Song MO, Hwang ES. Detection of human bocavirus in children hospitalized because of acute gastroenteritis. J Infect Dis. 2007 Oct 1;196(7):994-7.

70. Kantola K, Hedman L, Allander T, Jartti T, Lehtinen P, Ruuskanen O, et al. Serodiagnosis of human bocavirus infection. Clin Infect Dis. 2008 Feb 15;46(4):540-6.

71. Arnold JC, Singh KK, Spector SA, Sawyer MH. Human bocavirus: prevalence and clinical spectrum at a children's hospital. Clin Infect Dis. 2006 Aug 1;43(3):283-8.

72. Choi JH, Chung YS, Kim KS, Lee WJ, Chung IY, Oh HB, et al. Development of realtime PCR assays for detection and quantification of human bocavirus. J Clin Virol. 2008 Jul;42(3):249-53.

73. Schenk T, Huck B, Forster J, Berner R, Neumann-Haefelin D, Falcone V. Human bocavirus DNA detected by quantitative real-time PCR in two children hospitalized for lower respiratory tract infection. Eur J Clin Microbiol Infect Dis. 2007 Feb;26(2):147-9.

74. Souza EL, Ramos JG, Proenca-Modena JL, Diniz A, Carvalho G, Ciuffo I, AraújoNeto CA, Andrade SC, Souza LS, Arruda E, Silva L. Human bocavirus in very young infants hospitalized with acute respiratory infection in northeast Brazil. Journal of Tropical Pediatrics. 2009Apr;Ahead to print.

75. Botosso VF, Zanotto PM, Ueda M, Arruda E, Gilio AE, Vieira SE, et al. Positive selection results in frequent reversible amino acid replacements in the $G$ protein gene of human respiratory syncytial virus. PLoS Pathog. 2009 Jan;5(1):e1000254.

76. Walsh EE, Peterson DR, Falsey AR. Risk factors for severe respiratory syncytial virus infection in elderly persons. J Infect Dis. 2004 Jan 15;189(2):233-8.

77. Zheng H, Peret TC, Randolph VB, Crowley JC, Anderson LJ. Strain-specific reverse transcriptase PCR assay: means to distinguish candidate vaccine from wild-type strains of respiratory syncytial virus. J Clin Microbiol. 1996 Feb;34(2):334-7.

78. Peret TC, Hall CB, Hammond GW, Piedra PA, Storch GA, Sullender WM, et al. Circulation patterns of group A and B human respiratory syncytial virus genotypes in 5 communities in North America. J Infect Dis. 2000 Jun;181(6):1891-6.

79. Peret TC, Hall CB, Schnabel KC, Golub JA, Anderson LJ. Circulation patterns of genetically distinct group $\mathrm{A}$ and $\mathrm{B}$ strains of human respiratory syncytial virus in a community. J Gen Virol. 1998 Sep;79 ( Pt 9):2221-9.

80. Falsey AR, Erdman D, Anderson LJ, Walsh EE. Human metapneumovirus infections in young and elderly adults. J Infect Dis. 2003 Mar 1;187(5):785-90. 
81. Pitkaranta A, Arruda E, Malmberg H, Hayden FG. Detection of rhinovirus in sinus brushings of patients with acute community-acquired sinusitis by reverse transcription-PCR. J Clin Microbiol. 1997 Jul;35(7):1791-3.

82. Kuypers J, Martin ET, Heugel J, Wright N, Morrow R, Englund JA. Clinical disease in children associated with newly described coronavirus subtypes. Pediatrics. 2007 Jan;119(1):e70-6.

83. Echevarria JE, Erdman DD, Swierkosz EM, Holloway BP, Anderson LJ. Simultaneous detection and identification of human parainfluenza viruses 1, 2, and 3 from clinical samples by multiplex PCR. J Clin Microbiol. 1998 May;36(5):1388-91.

84. Ruest A, Michaud S, Deslandes S, Frost EH. Comparison of the Directigen flu A+B test, the QuickVue influenza test, and clinical case definition to viral culture and reverse transcription-PCR for rapid diagnosis of influenza virus infection. J Clin Microbiol. 2003 Aug;41(8):3487-93.

85. Hierholzer JC, Halonen PE, Dahlen PO, Bingham PG, McDonough MM. Detection of adenovirus in clinical specimens by polymerase chain reaction and liquid-phase hybridization quantitated by time-resolved fluorometry. J Clin Microbiol. 1993 Jul;31(7):1886-91.

86. Nystrom K, Biller M, Grahn A, Lindh M, Larson G, Olofsson S. Real time PCR for monitoring regulation of host gene expression in herpes simplex virus type 1-infected human diploid cells. J Virol Methods. 2004 Jun 15;118(2):83-94.

87. Mitchell DA, Marshall TK, Deschenes RJ. Vectors for the inducible overexpression of glutathione S-transferase fusion proteins in yeast. Yeast. 1993 Jul;9(7):715-22.

88. Bachand F, Autexier C. Functional reconstitution of human telomerase expressed in Saccharomyces cerevisiae. J Biol Chem. 1999 Dec 31;274(53):38027-31.

89. Camara AA, Silva JM, Ferriani VP, Tobias KR, Macedo IS, Padovani MA, et al. Risk factors for wheezing in a subtropical environment: role of respiratory viruses and allergen sensitization. J Allergy Clin Immunol. 2004 Mar;113(3):551-7.

90. Anderson LJ. Human bocavirus: a new viral pathogen. Clin Infect Dis. 2007 Apr 1;44(7):911-2.

91. Arden KE, McErlean P, Nissen MD, Sloots TP, Mackay IM. Frequent detection of human rhinoviruses, paramyxoviruses, coronaviruses, and bocavirus during acute respiratory tract infections. J Med Virol. 2006 Sep;78(9):1232-40.

92. Choi EH, Lee HJ, Kim SJ, Eun BW, Kim NH, Lee JA, et al. The association of newly identified respiratory viruses with lower respiratory tract infections in Korean children, 20002005. Clin Infect Dis. 2006 Sep 1;43(5):585-92.

93. Foulongne V, Olejnik Y, Perez V, Elaerts S, Rodiere M, Segondy M. Human bocavirus in French children. Emerg Infect Dis. 2006 Aug;12(8):1251-3. 
94. Foulongne V, Rodiere M, Segondy M. Human Bocavirus in children. Emerg Infect Dis. 2006 May;12(5):862-3.

95. Kaplan NM, Dove W, Abu-Zeid AF, Shamoon HE, Abd-Eldayem SA, Hart CA. Human bocavirus infection among children, Jordan. Emerg Infect Dis. 2006 Sep;12(9):141820.

96. Kleines M, Scheithauer S, Rackowitz A, Ritter K, Hausler M. High prevalence of human bocavirus detected in young children with severe acute lower respiratory tract disease by use of a standard PCR protocol and a novel real-time PCR protocol. J Clin Microbiol. 2007 Mar;45(3):1032-4.

97. Kupfer B, Vehreschild J, Cornely O, Kaiser R, Plum G, Viazov S, et al. Severe pneumonia and human bocavirus in adult. Emerg Infect Dis. 2006 Oct;12(10):1614-6.

98. Lin F, Zeng A, Yang N, Lin H, Yang E, Wang S, et al. Quantification of human bocavirus in lower respiratory tract infections in China. Infect Agent Cancer. 2007;2:3.

99. McIntosh K. Human bocavirus: developing evidence for pathogenicity. J Infect Dis. 2006 Nov 1;194(9):1197-9.

100. Naghipour M, Cuevas LE, Bakhshinejad T, Dove W, Hart CA. Human bocavirus in Iranian children with acute respiratory infections. J Med Virol. 2007 May;79(5):539-43.

101. Qu XW, Duan ZJ, Qi ZY, Xie ZP, Gao HC, Liu WP, et al. Human bocavirus infection, People's Republic of China. Emerg Infect Dis. 2007 Jan;13(1):165-8.

102. Sloots TP, McErlean P, Speicher DJ, Arden KE, Nissen MD, Mackay IM. Evidence of human coronavirus HKU1 and human bocavirus in Australian children. J Clin Virol. 2006 Jan;35(1):99-102.

103. Smuts H, Hardie D. Human bocavirus in hospitalized children, South Africa. Emerg Infect Dis. 2006 Sep;12(9):1457-8.

104. Volz S, Schildgen O, Klinkenberg D, Ditt V, Muller A, Tillmann RL, et al. Prospective study of Human Bocavirus (HBoV) infection in a pediatric university hospital in Germany 2005/2006. J Clin Virol. 2007 Nov;40(3):229-35.

105. Chow BD, Huang YT, Esper FP. Evidence of human bocavirus circulating in children and adults, Cleveland, Ohio. J Clin Virol. 2008 Nov;43(3):302-6.

106. Endo R, Ishiguro N, Kikuta H, Teramoto S, Shirkoohi R, Ma X, et al. Seroepidemiology of human bocavirus in Hokkaido prefecture, Japan. J Clin Microbiol. 2007 Oct;45(10):3218-23.

107. Lin F, Guan W, Cheng F, Yang N, Pintel D, Qiu J. ELISAs using human bocavirus VP2 virus-like particles for detection of antibodies against HBoV. J Virol Methods. 2008 Apr;149(1):110-7. 
108. Nagai Y. Paramyxovirus replication and pathogenesis. Reverse genetics transforms understanding. Rev Med Virol. 1999 Apr-Jun;9(2):83-99.

109. Pozo F, Garcia-Garcia ML, Calvo C, Cuesta I, Perez-Brena P, Casas I. High incidence of human bocavirus infection in children in Spain. J Clin Virol. 2007 Nov;40(3):224-8.

110. I PM, Nelson EA, Cheuk ES, Leung E, Sung R, Chan PK. Pediatric hospitalization of acute respiratory tract infections with Human Bocavirus in Hong Kong. J Clin Virol. 2008 May;42(1):72-4.

111. Plouffe JF. Importance of atypical pathogens of community-acquired pneumonia. Clin Infect Dis. 2000 Aug;31 Suppl 2:S35-9.

112. Tozer SJ, Lambert SB, Whiley DM, Bialasiewicz S, Lyon MJ, Nissen MD, et al. Detection of human bocavirus in respiratory, fecal, and blood samples by real-time PCR. J Med Virol. 2009 Mar;81(3):488-93.

113. Arhur JL, Higgins GD, Davidson GP, Givney RC, Ratcliff, RM. A novel bocavirus associated with acute gastroenteritis in Australian children. PLoS Pathogens. 2009 Apr,5(4):e1000391. 